\title{
Do Term Premiums Matter? Transmission via Exchange Rate Dynamics
}

\author{
Mitsuru Katagiri ${ }^{*}$ \\ mkatagiri@imf.org \\ Koji Takahashi* \\ kouji.takahashi-2@boj.or.jp
}

Papers in the Bank of Japan Working Paper Series are circulated in order to stimulate discussion and comments. Views expressed are those of authors and do not necessarily reflect those of the Bank.

If you have any comment or question on the working paper series, please contact each author.

When making a copy or reproduction of the content for commercial purposes, please contact the Public Relations Department (post.prd8@boj.or.jp) at the Bank in advance to request permission. When making a copy or reproduction, the source, Bank of Japan Working Paper Series, should explicitly be credited. 


\title{
Do Term Premiums Matter? Transmission via Exchange Rate Dynamics*
}

\author{
Mitsuru Katagiri ${ }^{\dagger} \quad$ Koji Takahashi ${ }^{\ddagger}$
}

June 2017

\begin{abstract}
The macroeconomic effect of term premiums is a controversial issue both theoretically and quantitatively. In this paper, we explore the possibility that term premiums affect inflation and the real economy via exchange rate dynamics. For this purpose, we construct a small open economy model with limited asset market participation, focusing particularly on the empirical fact that uncovered interest parity (UIP) tends to hold for longer-term interest rate differentials. In a quantitative exercise, we estimate parameters using Japanese and U.S. data and show that changes in the term premiums of both Japanese and U.S. long-term yields have sizable effects on Japanese inflation rates via the yen-U.S. dollar exchange rate. This result implies that although decreasing domestic term premiums increased Japan's inflation rates via the exchange rate channel to some extent, it is almost equally influenced by foreign factors such as a rise in U.S. term premium.

Keywords: Exchange Rate; Term Premium; Uncovered Interest Rate Parity JEL Classification: E31, E52, E58
\end{abstract}

*The authors are grateful for comments from Ji Huang, Frank Packer, Giorgio Valente, Andrew Binnig, David Cook, Kosuke Aoki, Douglas Laxton, Toyoichiro Shirota, Toshitaka Sekine, Koji Nakamura, Tomohiro Tsuruga, Ichiro Muto, Hibiki Ichiue, Toshinao Yoshiba and Yoshihiko Hogen as well as participants of the Asian Bureau of Finance and Economic Research annual conference 2017. The authors are also grateful for support from Saki Inoue for data handling. Any remaining errors are the sole responsibility of the authors. The views expressed in this paper are those of the authors and do not necessarily reflect the official views of the Bank of Japan and the International Monetary Fund.

$\dagger$ International Monetary Fund. E-mail address: mkatagiri@imf.org

${ }^{\ddagger}$ Bank of Japan. E-mail address: kouji.takahashi-2@boj.or.jp 


\section{Introduction}

The macroeconomic effect of term premiums is a controversial issue both theoretically and quantitatively. Ever since the preferred-habitat hypothesis advocated by Modigliani and Sutch (1966), financial economists and practitioners have been keen on discussing how to better measure term premium and what are factors behind its development. In contrast, modern macroeconomic models developed under the dynamic stochastic general equilibrium framework had paid little attention to term premium assuming explicitly or implicitly that the efficient market hypothesis holds (Fama (1970)). In this case, long-term yields can be described by a future course of the overnight policy interest rate and thus the model has to have neither long-term yields nor term premium on top of the policy interest rate. Against this backdrop, Stein (2012) and Faust (2015) point out that there is no rigid theoretical background on the relationship between term premiums and economic activity. ${ }^{1}$ However, more recently, as exemplified by Chen, Cúrdia and Ferrero (2012) and others, there has emerged an interest in examining how a change in term premium affects the economy both theoretically and quantitatively by extending these macroeconomic models. This seems to reflect the fact that long-term bond purchase programs, introduced by many central banks in advanced economies, lower long-term interest rates mainly through reducing term premiums (see, e.g., D'Amico et al. (2012) and Bank of Japan $(2015,2016))$. Uncovering the transmission mechanism of these measures requires macroeconomic models to examine the relationship between term premiums and real activities.

This paper contributes to the literature by constructing a small open economy model with long-term bonds and examining whether term premiums affect the inflation rate and the real economy via exchange rate dynamics. Our aim here is to show what assumptions

\footnotetext{
${ }^{1}$ Stein (2012) takes a simple corporate finance example to examine the effect of term premiums on corporate investment and concludes that "[...] investment spending is decoupled from the term premium and is determined instead by the expected future path of short rates." Faust (2015) surveys literature on the relationship between term premiums and real economy and concludes that there is no stylized theoretical model to explain the effects of changes in term premiums on real economy.
} 
are necessary to make term premiums relevant to the economy and to quantify the effect of term premiums via the exchange rate channel. In addition, we explicitly incorporate the effects of monetary policy and term premium shocks overseas, which otherwise would incorrectly be captured as "other domestic shocks" in the analysis. Our model thus attempts to deepen our understanding of the relationship among term premiums, exchange rates, and inflation both from a theoretical and a quantitative perspective.

Our motivation for exploring the exchange rate channel is the observed relationship between long-term interest rate differentials and exchange rate dynamics. One of theoretical explanations for the relationship is uncovered interest parity (UIP) (i.e., that there should be a positive relationship between interest rate differentials and the future exchange rate change). Figure 1 plots the interest rate differentials of $n$-year bonds ( $n=0,2,5$, and 10) between Japan and the U.S. against changes in the yen-dollar exchange rate from $t$ to $t+n .^{2}$ The figure highlights that the theoretical prediction of UIP holds only for long-term interest rates: while yen-dollar exchange rate dynamics are almost uncorrelated with the interest rate differentials of policy rates (overnight rates) as well as 2-year government bonds, they are positively correlated for 5-year and 10-year government bonds. ${ }^{3}$ Since term premiums are the gap between long-term interest rates and the future path of short-term interest rates, the empirical observation that shortterm and long-term interest rates clearly have different effects on exchange rate dynamics suggests that changes in term premiums may influence the exchange rate and thus have an effect on inflation and the real economy.

In order to ensure that the model behaves in line with this observation, we incorporate the following two assumptions into a standard small open economy model. First, households cannot invest in foreign bonds and can only save by investing in domestic short-term and long-term bonds. This assumption can be interpreted as a kind of "home

\footnotetext{
${ }^{2}$ In the case of $n=0$, we calculated quarterly averages of daily exchange rate returns.

${ }^{3}$ The phenomenon that UIP is satisfied only for longer-term interest rates is observed not only for the yen-dollar exchange rate but also for the exchange rate of other currencies with the U.S. dollar. See, for example, Chinn and Meredith (2004) and Chinn (2006) for discussions of UIP for long-term yields differentials.
} 
bias" in households' investment behavior. This assumption is not unrealistic, since in practice Japanese households prefer to invest in domestic financial assets rather than foreign ones. This is illustrated in Figure 2, which shows the composition of Japanese household assets from the Flow of Funds statistics: in the third quarter of 2016, foreign assets accounted only for 1.4 percent of households' total asset holdings. The figure further shows that this extreme "home bias" is very stable and has changed little over the years. Although various explanations for this home bias, such as informational frictions, have been proposed, no consensus has been reached in the literature. ${ }^{4}$ Therefore, although the reasons for the home bias are an interesting issue in themselves, in this study we simply take it as given and focus on the implications.

The second assumption is that in this economy only a risk-neutral domestic arbitrager can trade both long-term foreign and domestic bonds. Furthermore, we assume that the domestic arbitrager does not trade short-term domestic and foreign bonds. ${ }^{5}$ This second assumption can be justified by the fact that most Japanese institutional investors tend to hold long-term rather than short-term bonds. Figure 3 provides a breakdown of the bond portfolios of institutional investors (financial institutions other than deposittaking corporations), which are the largest investors in foreign debt in Japan. The figure shows that the amount of short-term bonds they hold is almost negligible and that their portfolios consist mostly of long-term bonds, thus providing empirical justification for our second assumption. ${ }^{6}$

\footnotetext{
${ }^{4}$ See, for example, French and Poterba (1991) and Coeurdacier and Rey (2013) for details on "home bias" in portfolio choices. Note that Japanese households tend to hold far fewer risky assets than households in other developed countries. See Kinari and Tsutsui (2009), Fujiki, Hirakata and Shioji (2012), and Aoki, Michaelides and Nikolov (2016) for more details on the characteristics of asset holdings of Japanese households.

${ }^{5}$ Although foreign investors hold a substantial amount of short-term Japanese government bonds, we do not incorporate the role of such investors in our model. Rather, we leave the study of the relation between foreign investors' holdings of short-term bonds and the UIP for short-term yields as our future work.

${ }^{6}$ Again, the reason for Japanese bond investors' portfolio choice is an interesting issue, but we simply take it as given in this paper and focus on the implications.
} 
A noteworthy consequence of these assumptions is that they not only lead to UIP for long-term interest rates, as observed in the data, but also work as necessary conditions for term premiums to influence inflation rates via exchange rate dynamics in the model. As pointed out by Chen, Cúrdia and Ferrero (2012), changes in term premiums do not have any effects on the economy unless there is an agent who only has access to long-term bonds and whose actions are relevant to the economy. In our model, the domestic arbitrager who trades only in domestic and foreign long-term bonds takes this role. $^{7}$ The arbitrager's actions are relevant to the economy because the limited bond market participation assumption for households implies that only the arbitrager's actions determine the exchange rate in the model. In other words, if households had access to foreign bonds (or the arbitrager had access to short-term bonds), and consequently UIP holds not only for long-term interest rates but also for short-term interest rates, changes in term premiums would not have any effect on the inflation rate and the real economy in our model.

We estimate the parameters of the model using the yen-dollar exchange rate and data for the Japanese and U.S. economies and then quantitatively investigate the effects of term premiums on the exchange rate and inflation in Japan. The impulse response analysis suggests that term premiums have a significant effect on inflation via exchange rate dynamics. The decomposition of historical inflation rates based on the estimated model indicates that U.S. term premium shocks put a downward pressure on the Japan's inflation rate through the appreciation of the yen since 2008 after expanding LargeScale Asset Purchase (LSAP) by the Federal Reserve. From 2013, however, the decrease in the domestic term premium after the Bank of Japan's quantitative and qualitative easing (QQE) policy raised the inflation rate by about 0.4 percentage points by causing a depreciation of the exchange rate. Thus, the quantitative results imply that the exchange

\footnotetext{
${ }^{7}$ Chen, Cúrdia and Ferrero (2012) construct a closed-economy model with long-term bonds and assume that part of the households do not have access to short-term bonds, forcing them to borrow and lend only via long-term bonds. In their model, without the assumption that the part of households can only buy and sell long-term bonds, term premiums do not have any effects on inflation and the real economy.
} 
rate has been affected by both U.S. and Japanese term premiums, and it leads to nonnegligible impacts on the inflation rate in Japan.

The paper proceeds as follows. Section 2 provides a brief review of the literature related to our study. Section 3 then presents our small open economy new Keynesian model with limited bond market participation of households and the arbitrager, and explains the relationship between long-term interest rate differentials and exchange rates in the model. Next, Section 4 presents the estimation of model parameters and examines the policy effects of term premiums based on impulse response analyses and historical decompositions. Finally, Section 5 concludes.

\section{Literature Review}

The studies most closely related to ours are Andrés, López-Salido and Nelson (2004) and subsequent studies trying to investigate the role of term premiums. Specifically, Chen, Cúrdia and Ferrero (2012) construct a DSGE model in which some households only have access to long-term bonds and their consumption behavior is consequently influenced by term premiums. Our paper extends their model to a standard small open economy model à la Adolfson et al. $(2007,2008)$ and proposes a different (but compatible) mechanism for the policy effects of term premiums. In the literature subsequent to Chen, Cúrdia and Ferrero (2012), Wesolowski (2016) investigates the effects of term premiums in the context of a small open economy model similar to our own and estimates the model using data for Poland. Alpanda and Kabaca (2015) examine the effect of term premiums in a two-country DSGE model and show that U.S. unconventional monetary policy had strong international spillover effects. Another strand of literature related to our paper is that on the relationship between interest rate differentials and exchange rates, of which Engel (2014) provides a recent survey. Of particular relevance in this context is the study by Kano and Wada (2017), who focus on the relationship between long-term interest rate differentials and the yen-dollar exchange rates and conclude that most of the exchange rate dynamics since the introduction of Abenomics are explained by U.S. long-term interest rates. 
As stated above, term premiums have attracted more attention in the context of possible transmission mechanism of unconventional monetary policy such as large-scale asset purchases. A central focus of the literature is the quantitative easing policies employed in Japan, reflecting the fact that the Bank of Japan was the first to adopt such policies in the 2000s. Surveying empirical studies on the effects of unconventional monetary policies in Japan, Ugai (2007) concludes that quantitative easing supported banks whose funding had been impaired, but did not have a significant effect on the real economy, which suggests that the bank funding channel was the main transmission mechanism of quantitative easing in Japan. ${ }^{8}$ However, following the introduction of unconventional policies in other advanced economies to deal with the economic downturn in the wake of the 2008 global financial crisis, the rapidly growing literature on the subject has highlighted other possible transmission channels. The first is the so-called credit easing channel: it has been argued that direct credit to firms and banks by governments and central banks in lieu of distressed private financial intermediaries affects the real economy by counteracting the contraction of credit (see, e.g., Curdia and Woodford (2011), Gertler and Karadi (2011) and Gertler and Kiyotaki (2010)). A second possible channel is the portfolio balance channel, which was initially proposed by Tobin $(1961,1963,1969)$ and then further extended by others including Vayanos and Vila (2009) by incorporating investors' preferred habitat. Providing support for the portfolio balance hypothesis, Chodorow-Reich (2014) and Hanson and Stein (2015) empirically showed that a reduction in long-term yields through central bank long-term bond purchases induces investors that seek a certain level of yields because of accounting or institutional requirements to "reach for yields" and rebalance their portfolios. In the context of the present study, the most relevant aspect of the portfolio balance channel hypothesis is the assumption of heterogeneity across agents, which results in imperfect asset substitutability and allows unconventional policy to have a real effect. ${ }^{9}$

Like the portfolio balance channel hypothesis, our study introduces heterogeneity

\footnotetext{
${ }^{8}$ For a detailed discussion of the bank funding channel, see Joyce et al. (2012).

${ }^{9}$ Credit imperfections and heterogeneity across agents are also key assumptions of the credit easing channel hypothesis, as discussed by Curdia and Woodford (2011).
} 
across agents, in which it is assumed that some investors have limited access to foreign bonds and there is an arbitrager. However, in contrast with studies on the portfolio balance channel, we focus on the relationships between term premiums and the exchange rate, which is an aspect that has not been extensively examined in the literature yet.

\section{Model}

The model follows a standard small open dynamic general equilibrium framework with long-term bonds. The home country economy consists of households, an arbitrager, and several types of firms, which produce consumption goods, intermediate goods, export goods, and import goods, respectively. In addition, the economy in the rest of the world (foreign economy) is described by a small-scale new Keynesian model. In the spirit of small open economy models, the foreign economy is assumed to be independent of the home economy, while the home economy is assumed to be influenced by the foreign economy through, for example, the exchange rate, the demand for export goods, and the prices of import goods. Each type of agents' behavior in the home economy as well as the foreign economy is described in turn.

\subsection{Households}

There is a continuum of households in the home economy that supplies a differentiated labor force indexed by $h \in(0,1)$ to obtain wage income $W_{t}(h) L_{t}(h)$, where $W_{t}(h)$ denotes the nominal wage and $L_{t}(h)$ denotes the hours worked of each household $h$. In addition, because all firms in the economy are owned by households and households also invest in the arbitrager, households obtain profits $D_{t}$ from firms and the arbitrager as another source of their income. Households allocate their income to the consumption basket $C_{t}$ and savings. The consumption basket consists of domestic and foreign consumption goods,

$$
C_{t}=\left[(1-\delta)^{\frac{1}{\eta}} C_{d, t}^{\frac{\eta-1}{\eta}}+\delta^{\frac{1}{\eta}} C_{f, t}^{\frac{\eta-1}{\eta}}\right]^{\frac{\eta}{\eta-1}}
$$


where $C_{d, t}$ and $C_{f, t}$ are domestic and imported consumption goods, respectively. $\delta$ and $\eta$ are the parameters for the share of imported consumption goods in the consumption bascket and for the elasticity between domestic and foreign goods, respectively. The price level of the consumption basket (i.e., the consumer price index, CPI) is given by

$$
P_{t} C_{t}=P_{d, t} C_{d, t}+P_{f, t} C_{f, t}
$$

where $P_{d, t}$ and $P_{f, t}$ are the prices of domestic and imported consumption goods. Savings take two forms: nominal one-period domestic bonds, $B_{t}$, and long-term domestic bonds, $B_{t}^{L}$. Following Woodford (2001), long-term bonds take the form of perpetuities which pay a decaying coupon $\kappa^{s}$ at $t+1+s$. Further, following Chen, Cúrdia and Ferrero (2012), households are assumed to pay time-varying transaction cost $\zeta_{t}$ per unit of long-term bonds. This transaction cost, which is introduced to describe the preferred habitat behavior of investors, is a source of term premiums in this model, and follows the exogenous process

$$
\zeta_{t}-\zeta=\rho_{\zeta}\left(\zeta_{t-1}-\zeta\right)+\varepsilon_{\zeta, t}
$$

In the quantitative analysis, $\varepsilon_{\zeta, t}$ might be regarded to capture the policy shock brought about by quantitative easing, but strictly speaking, we have not modeled how quantitative easing affects the level of term premiums and hence the central bank in this model does not calibrate its monetary policy through this channel. Therefore, once we have quantitatively established the effects of term premiums on inflation and the exchange rate, it is straightforward to numerically translate the effects of term premiums into the effects of unconventional monetary policy easing.

Households face the following budget constraint:

$$
P_{t} C_{t}+B_{t}+\left(1+\zeta_{t}\right) P_{t}^{L} B_{t}^{L}=R_{t-1} B_{t-1}+P_{t}^{L} R_{t}^{L} B_{t-1}^{L}+W_{t}(h) L_{t}(h)+D_{t},
$$

where $P_{t}^{L}$ is the price of long-term bonds and $R_{t}^{L}=\frac{1}{P_{t}^{L}}+\kappa$ is the long-term interest rate. Note that households cannot invest in foreign bonds but only in domestic bonds. This limited bond market participation assumption for households is based on the empirical fact that Japanese households hold almost negligible amounts of foreign assets, as shown 
in Figure 2. Households choose their consumption $C_{t}$ and short-term and long-term bonds, $B_{t}$ and $B_{t}^{L}$, to maximize their lifetime utility,

$$
E_{0} \sum_{t=0}^{\infty} \beta^{t}\left[\log \left(C_{t}-\varkappa C_{t-1}\right)-\psi \frac{L_{t}(h)^{1+\nu}}{1+\nu}\right],
$$

subject to constraints (1) and $(2) . \beta \in(0,1)$ is the constant discount factor and $\varkappa$ is the parameter for habit formation.

There are competitive labor agencies who aggregate the labor services provided by each household $h$ into homogeneous labor $L_{t}$ based on the following constant elasticity of substitution (CES) function:

$$
L_{t}=\left(\int_{0}^{1} L_{t}(h)^{\frac{1}{\lambda w}} d h\right)^{\lambda_{w}}
$$

where $\lambda_{w}>1$ is the markup parameter. Let $W_{h, t}$ be the nominal wage rate for household $h$. The aggregate nominal wage $W_{t}$ is defined as

$$
W_{t}=\left(\int_{0}^{1} W_{t}(h)^{\frac{1}{1-\lambda w}} d h\right)^{1-\lambda_{w}}
$$

and the demand function for each household's labor services is then derived as a result of profit maximization by the labor agencies,

$$
L_{t}(h)=\left(\frac{W_{t}(h)}{W_{t}}\right)^{\frac{\lambda_{w}}{1-\lambda_{w}}} L_{t}
$$

Given this demand function for their labor services, households monopolistically supply differentiated labor $L_{t}(h)$ and set their wages $W_{t}(h)$ on a staggered basis à la Calvo (1983). In each period, a fraction of households, $0<\xi_{w}<1$, set their wages based on the partial indexation rule $W_{t}(h)=\left(\pi_{t-1} e^{\gamma_{t-1}}\right)^{\iota_{w}}\left(\pi e^{\gamma}\right)^{1-\iota_{w}} W_{t-1}(h)$, where $\pi_{t-1}$ and $e^{\gamma_{t-1}}$ are the aggregate inflation rate and the aggregate productivity growth rate in period $t-1$, and $\pi$ and $e^{\gamma}$ are their steady state values. The remaining fraction $1-\xi_{w}$ of households chooses $\tilde{W}_{t}(h)$ to maximize

$$
\max _{\tilde{W}_{t}(h)} E_{t} \sum_{s=0}^{\infty}\left(\beta \xi_{w}\right)^{s}\left[\Xi_{t+s} \tilde{W}_{t+s}(h) L_{t+s}(h)-\psi \frac{L_{t+s}(h)^{1+\nu}}{1+\nu}\right],
$$

where $\Xi_{t}$ is the marginal utility of consumption in nominal terms,

$$
P_{t} \Xi_{t} \equiv \frac{1}{C_{t}-\varkappa C_{t-1}}-\frac{\beta \varkappa}{C_{t+1}-\varkappa C_{t}}
$$


Nominal wage rates $\tilde{W}_{t+s}(h)$ are determined by the following law of motion:

$$
\tilde{W}_{t+s}(h)=\left(\pi_{t+s-1} e^{\gamma_{t+s-1}}\right)^{\iota w}\left(\pi e^{\gamma}\right)^{1-\iota w} \tilde{W}_{t+s-1}(h),
$$

for $s \geq 1$, and labor demand $L_{t+s}(h)$ is determined by $(3)$ and $\tilde{W}_{t+s}(h)$. Given each household's optimization, wage inflation dynamics can be described by a recursive structure with the two auxiliary variables, $x_{1, t}^{w}$ and $x_{2, t}^{w}$, as follows:

$$
\left[\frac{1-\xi_{w}\left(\frac{w_{t-1}}{w_{t}} \Pi_{w, t}^{*}\right)^{\frac{1}{1-\lambda_{w}}}}{1-\xi_{w}}\right]^{1-\lambda_{w}}=\left(\frac{\lambda_{w}}{w_{t}} \frac{x_{1, t}^{w}}{x_{2, t}^{w}}\right)^{\frac{1-\lambda_{w}}{1-(1+\nu) \lambda_{w}}}
$$

where $w_{t}=W_{t} / P_{t}$ and $\Pi_{w, t}^{*}=\left(\pi_{t-1} e^{\gamma_{t-1}}\right)^{\iota_{w}}\left(\pi e^{\gamma}\right)^{1-\iota_{w}} /\left(\pi_{t} e^{\gamma_{t}}\right)$. These two auxiliary variables, $x_{1, t}^{w}$ and $x_{2, t}^{w}$, follow the following laws of motion:

$$
\begin{aligned}
& x_{1, t}^{w}=\psi L_{t}^{1+\nu}+\beta \xi_{w} E_{t}\left[\left(\frac{w_{t}}{w_{t+1}} \Pi_{w, t+1}^{*}\right)^{\frac{\lambda_{w}(1+\nu)}{1-\lambda_{w}}} x_{1, t+1}^{w}\right], \\
& x_{2, t}^{w}=\Lambda_{t} L_{t}+\beta \xi_{w} E_{t}\left[\left(\frac{w_{t}}{w_{t+1}}\right)^{\frac{\lambda_{w}}{1-\lambda_{w}}}\left(\Pi_{w, t+1}^{*}\right)^{\frac{1}{1-\lambda_{w}}} x_{2, t+1}^{w}\right],
\end{aligned}
$$

where $\Lambda_{t}=P_{t} A_{t} \Xi_{t}$.

\subsection{Consumption Good Firms}

The domestic consumption good firms produce the final good, $Y_{d, t}$, by aggregating the intermediate goods, $Y_{d, t}(i)$, based on the following CES production function in a competitive market:

$$
Y_{d, t}=\left(\int_{0}^{1} Y_{d, t}(i)^{\frac{1}{\lambda_{c}}} d i\right)^{\lambda_{c}},
$$

where $\lambda_{c}>1$ is the markup parameter. Let $P_{d, t}(i)$ be the price of each intermediate good. The price index for domestic intermediate goods, $P_{d, t}$, is then defined as

$$
P_{d, t}=\left(\int_{0}^{1} P_{d, t}(i)^{\frac{1}{1-\lambda_{c}}} d i\right)^{1-\lambda_{c}}
$$

and the demand for each intermediate good is derived based on profit maximization by consumption good firms,

$$
Y_{d, t}(i)=\left(\frac{P_{d, t}(i)}{P_{d, t}}\right)^{\frac{\lambda_{c}}{1-\lambda_{c}}} Y_{d, t} .
$$




\subsection{Intermediate Goods Firms}

A continuum of intermediate goods firms indexed by $i$ produce differentiated intermediate goods using labor $L_{t}(i)$ and imported intermediate inputs $Z_{t}(i)$ based on the following technology:

$$
Y_{d, t}(i)=\left[Z_{t}(i)\right]^{\alpha}\left[A_{t} L_{t}(i)\right]^{1-\alpha}
$$

where $A_{t}$ is labor-augmenting technology in period $t$. Let $\gamma_{t}=A_{t} / A_{t-1}$ and assume that $\gamma_{t}$ follows the process

$$
\log \left(\frac{\gamma_{t}}{\gamma}\right)=\rho_{\gamma} \log \left(\frac{\gamma_{t-1}}{\gamma}\right)+\varepsilon_{\gamma, t}
$$

Intermediate goods firms' optimization problem means that nominal marginal cost $M C_{d, t}$ is given by

$$
M C_{d, t}=\frac{\left(P_{f, t}\right)^{\alpha} W_{t}^{1-\alpha}}{\alpha^{\alpha}(1-\alpha)^{1-\alpha} A_{t}^{1-\alpha}}
$$

where $P_{f, t}$ is the price of imported goods.

Under monopolistic competition, intermediate good firm $i$ faces consumption good firms' demand $Y_{d, t}(i)=\left(P_{d, t}(i) / P_{d, t}\right)^{\frac{\lambda_{c}}{1-\lambda_{c}}} Y_{d, t}$ and maximizes its discounted profits by setting the price of its differentiated product on a staggered basis à la Calvo (1983). In each period, a fraction of intermediate good firms, $1-\xi_{d} \in(0,1)$, reoptimizes prices while the remaining fraction $\xi_{d}$ indexes prices to a weighted average of past and steadystate inflation $\left(\pi_{d, t-1}\right)^{\iota_{d}} \pi^{1-\iota_{d}}$, where $\iota_{d} \in[0,1]$ is the relative weight on past inflation and $\pi_{d, t}=P_{d, t} / P_{d, t-1}$. Hence, the intermediate good firm $i$ that reoptimizes prices in the current period chooses its prices so as to maximize,

$$
\max _{\tilde{P}_{d, t}(i)} E_{t} \sum_{s=0}^{\infty}\left(\beta \xi_{d}\right)^{s} \Xi_{t+s}\left[\tilde{P}_{d, t+s}(i)-v_{d, t} M C_{d, t+s}\right] Y_{d, t+s}(i),
$$

where $v_{d, t}$ is a marginal cost shock for domestic intermediate good firms, and it follows the process,

$$
\log \left(v_{d, t}\right)=\rho_{d} \log \left(v_{d, t-1}\right)+\varepsilon_{d, t}
$$

Also, $\tilde{P}_{d, t+s}(i)$ is determined by the following law of motion,

$$
\tilde{P}_{d, t+s}(i)=\left(\pi_{d, t+s-1}\right)^{\iota_{d}}(\pi)^{1-\iota_{d}} \tilde{P}_{d, t+s-1}(i)
$$


for $s \geq 1$, and the demand for $Y_{d, t+s}(i)$ is determined by (4) and $\tilde{P}_{d, t+s}(i)$. As a result of the intermediate good firms' optimization, inflation dynamics $\pi_{d, t}$ can be described by a recursive structure with the two auxiliary variables, $x_{1, t}^{d}$ and $x_{2, t}^{d}$, as follows:

$$
\left[\frac{1-\xi_{d}\left(\Pi_{d, t}^{*}\right)^{\frac{1}{1-\lambda_{d}}}}{1-\xi_{d}}\right]^{1-\lambda_{d}}=\lambda_{c} \frac{x_{1, t}^{d}}{x_{2, t}^{d}}
$$

where $\Pi_{d, t}^{*}=\left(\pi_{d, t-1}\right)^{\iota_{d}} \pi^{1-\iota_{d}} / \pi_{d, t}$. Those two auxiliary variables, $x_{1, t}^{d}$ and $x_{2, t}^{d}$, follow the following laws of motion:

$$
\begin{aligned}
& x_{1, t}^{d}=\Lambda_{t} p_{d, t} y_{d, t} v_{d, t} m c_{d, t}+\beta \xi_{d} E_{t}\left[\left(\Pi_{d, t+1}^{*}\right)^{\frac{\lambda_{c}}{1-\lambda_{c}}} x_{1, t+1}^{d}\right], \\
& x_{2, t}^{d}=\Lambda_{t} p_{d, t} y_{d, t}+\beta \xi_{d} E_{t}\left[\left(\Pi_{d, t+1}^{*}\right)^{\frac{1}{1-\lambda_{c}}} x_{2, t+1}^{d}\right],
\end{aligned}
$$

where $y_{d, t}=Y_{d, t} / A_{t}, m c_{d, t}=M C_{d, t} / P_{t}$, and $p_{d, t}=P_{d, t} / P_{t}$.

\subsection{Imported Goods Firms}

The imported goods firms are classified into two groups: intermediate goods firms and final good firms. A continuum of intermediate goods firms indexed by $f$ purchases foreign goods from abroad at the foreign price $P_{t}^{*}$, and sell them to final good firms as differentiated foreign goods $Y_{f, t}(f)$ at the price of $P_{f, t}(f)$. Then, the final good firms aggregate these differentiated imported goods into the final imported good $Y_{f, t}$ using the CES aggregator, and sell it at the price of $P_{f, t}$. The final imported good is used for consumption $C_{f, t}$ or intermediate inputs for domestic intermediate goods firms, $Z_{t}$, as is shown in (5).

The demand function for each intermediate good $Y_{f, t}(f)$ is derived as a result of profit maximization of the final good firm as,

$$
Y_{f, t}(f)=\left(\frac{P_{f, t}(f)}{P_{f, t}}\right)^{\frac{\lambda_{f}}{1-\lambda_{f}}} Y_{f, t} .
$$

Given this demand function, the intermediate goods firms monopolistically supply differentiated intermediate goods. Since the intermediate good firms in the imported sector purchase foreign goods from abroad, their nominal marginal cost, $M C_{f, t}$, is defined as,

$$
M C_{f, t}=\frac{P_{t}^{*}}{Q_{t}}
$$


where $Q_{t}$ is the nominal exchange rate.

Under monopolistic competition, intermediate goods firm $f$ for imported goods faces final good firms' demand (Equation (6)), and maximizes its discounted profits by setting the price of its differentiated products on a staggered basis à la Calvo (1983). In each period, a fraction of intermediate good firms, $1-\xi_{f} \in(0,1)$, reoptimizes prices while the remaining fraction $\xi_{f}$ indexes prices to a weighted average of past and steady-state inflation $\left(\pi_{f, t-1}\right)^{\iota_{f}} \pi^{1-\iota_{f}}$, where $\iota_{f} \in[0,1]$ is the relative weight on past inflation and $\pi_{f, t}=P_{f, t} / P_{f, t-1}$. Hence, the intermediate good firm $f$ that reoptimizes prices in the current period chooses its prices so as to maximize,

$$
\max _{\tilde{P}_{f, t}(f)} E_{t} \sum_{s=0}^{\infty}\left(\beta \xi_{f}\right)^{s} \Xi_{t+s}\left[\tilde{P}_{f, t+s}(f)-v_{f, t} M C_{f, t+s}\right] Y_{f, t+s}(f),
$$

where $v_{f, t}$ is a marginal cost shock for intermediate goods firms for imported goods, and it follows the process,

$$
\log \left(v_{f, t}\right)=\rho_{f} \log \left(v_{f, t-1}\right)+\varepsilon_{f, t} .
$$

Also, $\tilde{P}_{f, t+s}(f)$ is determined by the following law of motion,

$$
\tilde{P}_{f, t+s}(f)=\left(\pi_{f, t+s-1}\right)^{\iota_{f}}(\pi)^{1-\iota_{f}} \tilde{P}_{f, t+s-1}(f),
$$

for $s \geq 1$, and the demand for $Y_{f, t+s}(f)$ is determined by $(6)$ and $\tilde{P}_{f, t+s}(f)$. Then, by assuming the optimal price setting under the staggered prices with partial indexation, the inflation dynamics of imported price, $\pi_{f, t}=P_{f, t} / P_{f, t-1}$, are described by a recursive structure with two auxiliary variables similarly to those of domestic good prices in the previous subsection. Since the imported goods firms set the imported prices in the home currency on a staggered basis, they cannot reflect all of fluctuations in their marginal cost caused by exchange rate changes, thus making the pass-through to the imported prices not perfect in the short-run.

\subsection{Exported Goods Firms}

The exported goods firms purchase domestic consumption goods $Y_{d, t}$, and sell them to foreign customers at the price of $P_{x, t}^{*}(x)$ in a foreign currency basis. The demand function 
for exported goods $Y_{x, t}(x)$ in an international market is assumed to depend on the relative price of exported goods to foreign price level, $P_{x, t}^{*}(x) / P_{t}^{*}$, the foreign output gap, $y_{t}^{*}$, and a trade balance shock, $v_{x}$, and it is determined by the following reduced form demand function,

$$
Y_{x, t}(x)=\left(\frac{P_{x, t}^{*}(x)}{P_{t}^{*}}\right)^{\frac{\lambda_{x}}{1-\lambda_{x}}}\left(y_{t}^{*}\right)^{\theta} \exp \left(v_{x, t}\right),
$$

where $\lambda_{x}$ and $\theta$ are parameters for elasticity of demand to relative price of exported goods and foreign output gap, respectively. Also, the trade balance shock follows

$$
\log \left(v_{x, t}\right)=\rho_{x} \log \left(v_{x, t-1}\right)+\varepsilon_{x, t} .
$$

Given this demand function, the exported goods firms monopolistically supply exported goods. Since the exported good firms purchase domestic consumption goods and sell them to foreign customers, their nominal marginal cost, $M C_{x, t}$, is defined as,

$$
M C_{x, t}=P_{d, t}
$$

The exported goods firms are assumed to set the exported prices in the foreign currency on the staggered basis with partial indexation, and maximize their profits in the home currency. Therefore, the exchange rate has effects on the export prices measured by home currency and consequently on the amount of exports as well as their profits in home currency. More concretely, under monopolistic competition, exported good firm $x$ faces final good firms' demand (Equation (7)), and maximizes its discounted profits by setting the price of its differentiated products on a staggered basis à la Calvo (1983). In each period, a fraction of exported goods firms, $1-\xi_{x} \in(0,1)$, reoptimizes prices while the remaining fraction $\xi_{x}$ indexes prices to a weighted average of past and steady-state inflation $\left(\pi_{x, t-1}^{*}\right)^{\iota_{x}} \pi^{* 1-\iota_{x}}$, where $\iota_{x} \in[0,1]$ is the relative weight on past inflation and $\pi_{x, t}^{*}=P_{x, t}^{*} / P_{x, t-1}^{*}$. Hence, exported goods firm $x$ that reoptimizes prices in the current period chooses its prices so as to maximize,

$$
\max _{\tilde{P}_{x, t}^{*}(x)} E_{t} \sum_{s=0}^{\infty}\left(\beta \xi_{x}\right)^{s} \Xi_{t+s}\left[\tilde{P}_{x, t+s}^{*}(x) / Q_{t+s}-M C_{x, t+s}\right] Y_{x, t+s}(x) .
$$

Also, $\tilde{P}_{x, t+s}^{*}(x)$ is determined by the following law of motion, 


$$
\tilde{P}_{x, t+s}^{*}(x)=\left(\pi_{x, t+s-1}^{*}\right)^{\iota_{x}}\left(\pi^{*}\right)^{1-\iota_{x}} \tilde{P}_{x, t+s-1}^{*}(x),
$$

for $s \geq 1$, and the demand for $Y_{x, t+s}(x)$ is determined by $(7)$ and $\tilde{P}_{x, t+s}^{*}(x)$.

As a result of profit maximization of the exported firms, the inflation dynamics of exported price, $\pi_{x, t}^{*}=P_{x, t}^{*} / P_{x, t-1}^{*}$, are described by a recursive structure with two auxiliary variables similarly to those of domestic prices.

\subsection{Central Bank}

The central bank in the home country sets short-term nominal interest rates depending on the year-on-year inflation rate and output growth rate. In particular, it follows the Taylor-type policy rule with interest rate smoothing,

$$
R_{t}=\left(R_{t-1}\right)^{\rho_{R}}\left[R\left(\frac{\left[\Pi_{j=1}^{4} \pi_{t-j+1}\right]^{1 / 4}}{\bar{\pi}_{t}}\right)^{1+\phi_{\pi}}\left(\frac{\left[\Pi_{j=1}^{4} g_{t-j+1}^{y}\right]^{1 / 4}}{e^{\gamma}}\right)^{\phi_{y}}\right]^{1-\rho_{R}} v_{m, t}
$$

where $g_{t}^{y}=Y_{d, t} / Y_{d, t-1}$ and $\bar{\pi}_{t}$ is the target inflation rate for the central bank. The target inflation rate is assumed to be time varying and follow the process,

$$
\log \left(\frac{\bar{\pi}_{t}}{\bar{\pi}}\right)=\rho_{t p} \log \left(\frac{\bar{\pi}_{t-1}}{\bar{\pi}}\right)+\varepsilon_{t p, t} .
$$

The central bank can deviate from the rule by adjusting a short-term interest rate shock, $v_{m, t}$. The short-term interest rate shock in period $t$ consists of two parts: a temporary interest rate shock in period $t$ and an interest rate news shock in $t-12 .^{10}$ That is,

$$
\begin{aligned}
\log \left(v_{m, t}\right) & =\rho_{m} \log \left(v_{m, t-1}\right)+\varepsilon_{m, t} \\
\varepsilon_{m, t} & =\hat{\varepsilon}_{m, t}+\tilde{\varepsilon}_{m, t-12}
\end{aligned}
$$

\footnotetext{
${ }^{10}$ Basically we can add more news shocks with different lag lengths to the model. However, increasing the number of news shocks does not necessarily improve the goodness of fits of the models as shown by Milani and Treadwell (2012). Furthermore, in April 2013, the Bank of Japan has announced that it would double the monetary base in two years. To fully capture the forward guidance effect of this announcement, we chose the lag length of 12 quarters.
} 
where $\hat{\varepsilon}_{m, t}$ and $\tilde{\varepsilon}_{m, t}$ are independent iid shocks. The interest rate news shock $\tilde{\varepsilon}_{m, t}$ is supposed to capture the following two things. First, it is supposed to capture the positive deviations from the policy Bank of Japan introduced a negative interest rate policy in 2016, the zero lower bound was supposed to be binding before 2015. Since the existence of the zero lower bound is known in advance and influences the economy when it is recognized, such deviations should be captured by the news shock rather than the contemporaneous monetary policy shock. Second, the interest rate news shock is supposed to capture the central bank's commitment to low interest rates. Since the central bank's commitment to future monetary easing has effects on inflation rates and real economy right after they announce the commitment, the policy effect through the "forward guidance" should be captured by the news shock as well.

\subsection{Arbitrager}

In order to close the international bond market, we introduce a risk-neutral arbitrager who trades domestic and foreign bonds to maximize his instantaneous profits. Based on the empirical fact shown in Figure 3 that Japanese institutional investors almost exclusively hold long-term bonds, we assume that the arbitrager can trade only domestic and foreign long-term bonds and cannot trade domestic or foreign short-term bonds. That is, the arbitrager's optimization problem is formulated as

$$
\max _{B_{t}^{L}, B_{t}^{L *}} E_{t}\left[\beta_{A, t}\left\{\left(R_{t+1}^{L *}+\phi_{t+1}\right) \frac{P_{t+1}^{L *}}{Q_{t+1}} B_{t}^{L *}+R_{t+1}^{L} P_{t+1}^{L} B_{t}^{L}\right\}-\left(\frac{P_{t}^{L *}}{Q_{t}} B_{t}^{L *}+P_{t}^{L} B_{t}^{L}\right)\right],
$$

where $P_{t}^{L *}, R_{t+1}^{L *}$, and $B_{t}^{L *}$ are the price of, the return on, and the amount of foreign long-term bonds held by the arbitrager and $\beta_{A, t}$ is the discount factor for the arbitrager. Foreign long-term bonds, similar to domestic long-term bonds, take the form of perpetuities which pay a decaying coupon $\kappa^{s}$ at $t+1+s$, so that the relationship $R_{t}^{L *}=1 / P_{t}^{L *}+\kappa$ is satisfied. To ensure the existence of a steady state in the small open economy, it is assumed that there exists a tiny time varying risk-premium, $\phi_{t},{ }^{11}$ which is given by the

\footnotetext{
${ }^{11}$ The risk premium $\phi$ can also be interpreted as the transaction cost involved in trading foreign bonds, since domestic investor can only earn $R_{t+1}^{L *}+\phi_{t+1}$ on foreign bonds, while foreign investors earn $R_{t+1}^{L *}$.
} 
following rule:

$$
\phi_{t}-\phi=-\Phi\left(B_{t}^{L *}-B^{L *}\right)+v_{q, t} .
$$

Here, $v_{q, t}$ is a real exchange rate shock and assumed to follow the process

$$
v_{q, t}=\rho_{q} v_{q, t-1}+\varepsilon_{q, t},
$$

where $\varepsilon_{q, t}$ is an iid shock. This rule for $\phi_{t}$ means that the time-varying risk premium on foreign bonds increases (decreases) when net foreign assets held by the arbitrager decrease (increase) and thus pushes back the amount of foreign assets to their steady state value. Without this risk premium, there would not exist a steady state for foreign assets. $^{12}$ The arbitrager's profits are assumed to be distributed to households in lumpsum payments.

By combining the arbitrager's first order conditions with respect to $B_{t}^{L}$ and $B_{t}^{L *}$, and deleting the discount factor $\beta_{A, t}$, the following UIP condition with respect to long-term interest rates is derived:

$$
E_{t}\left[\frac{P_{t+1}^{L *}}{P_{t}^{L *}}\left(R_{t+1}^{L *}+\phi_{t+1}\right) \frac{Q_{t}}{Q_{t+1}}\right]=E_{t}\left[\frac{P_{t+1}^{L}}{P_{t}^{L}} R_{t+1}^{L}\right] .
$$

This UIP condition with respect to long-term interest rates shows that the expected change in the exchange rate is determined by the difference between the expected return on holding domestic long-term bonds for one period and that on holding foreign long-term bonds for one period. Note that this UIP condition is not satisfied for short-term interest rates due to the limited bond market participation of households and the arbitrager, which implies that the connection between interest differentials and the exchange rate is much weaker for short-term interest rates than for long-term interest rates.

\footnotetext{
${ }^{12}$ See Schmitt-Grohé and Uribe (2003) for more details on ways to close a small open economy model, including the assumption of the existence of a risk premium on foreign bonds. A risk-premium shock can be also interpreted as a real exchange rate shock, since it exogenously affects the real exchange rate.
} 


\subsection{Market Clearing}

To close the model, the market clearing conditions for the domestic and imported goods markets need to be satisfied. The market clearing condition for domestic goods is

$$
P_{d, t} Y_{d, t}=P_{d, t} C_{d, t}+I_{d}+P_{d, t} Y_{x, t},
$$

where $I_{d}$ is nominal corporate investment. This market clearing condition states that domestic goods are allocated to consumption, investment, or export. Since capital accumulation is not explicitly modeled here, nominal corporate investment is assumed to be constant. The market clearing condition for imported goods, on the other hand, is formulated as

$$
Y_{f, t}=C_{f, t}+Z_{t},
$$

which states that imported goods are used for consumption or as intermediate input.

In addition to these two market clearing conditions being satisfied, the capital market for foreign assets needs to be balanced. This condition is given by the following current account condition:

$$
P_{t}^{L *} B_{t}^{L *}-\left(R_{t}^{L *}+\phi_{t}\right) P_{t}^{L *} B_{t-1}^{L *}=P_{x, t}^{*} Y_{x, t}-P_{t}^{*} Y_{f, t} .
$$

This current account condition is derived by aggregating households' budget constraints and the arbitrager's profits and by assuming a zero net supply of domestic short-term and long-term bonds. ${ }^{13}$ The left-hand side of this condition represents the income balance plus net increases in foreign assets, while the right-hand side represents the trade balance. Note that in this model the income balance is determined only by long-term bonds $B_{t}^{L *}$, reflecting the assumption that households cannot access foreign bonds and the arbitrager trades only long-term bonds.

\subsection{Foreign Economy}

The foreign economy is given by a small-scale new Keynesian model. In the spirit of small open economy models, the foreign economy is assumed not to be influenced by

\footnotetext{
${ }^{13}$ Note that the zero net supply of domestic bonds is assumed here because the steady-state level of domestic bonds does not influence the dynamics of the model.
} 
economic activity in the home economy, while it influences the home economy through imports/exports and the exchange rate.

The foreign economy's output gap $y_{t}^{*}$ and inflation rate $\pi_{t}^{*}$ are described by the following IS curve,

$$
\Lambda_{t}^{*}=\beta E_{t}\left[\Lambda_{t+1}^{*} \frac{R_{t}^{*} e^{\gamma_{t+1}^{*}}}{\pi_{t+1}^{*}}\right]
$$

and the New Keynesian Phillips curve,

$$
\frac{\pi_{t}^{*}}{\pi^{*}}=\beta E_{t}\left(\frac{\pi_{t+1}^{*}}{\pi^{*}}\right)\left(y_{t}^{*}\right)^{\varpi^{*}} v_{p, t}^{*}
$$

where $\varpi^{*}$ is the parameter for the elasticity of inflation to the output gap. The marginal utility of consumption, $\Lambda_{t}^{*}$, is defined by

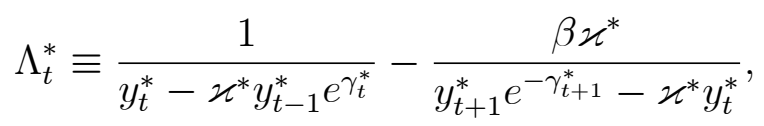

where $\varkappa^{*}$ is the parameter for habit formation. Here, $\gamma_{t}^{*}$ and $v_{p, t}^{*}$ are shocks to productivity growth and markups, respectively, and follow the process,

$$
\begin{aligned}
\log \left(\frac{\gamma_{t}^{*}}{\gamma^{*}}\right) & =\rho_{\gamma}^{*} \log \left(\frac{\gamma_{t-1}^{*}}{\gamma^{*}}\right)+\varepsilon_{\gamma, t}^{*}, \\
\log \left(v_{p, t}^{*}\right) & =\rho_{p}^{*} \log \left(v_{p, t-1}^{*}\right)+\varepsilon_{p, t}^{*} .
\end{aligned}
$$

Finally, nominal interest rates are determined by the central bank following the Taylor-type policy rule as in the home economy,

$$
R_{t}^{*}=\left(R_{t-1}^{*}\right)^{\rho_{R}^{*}}\left[R^{*}\left(\frac{\left[\Pi_{j=1}^{4} \pi_{t-j+1}^{*}\right]^{1 / 4}}{\bar{\pi}_{t}^{*}}\right)^{1+\phi_{\pi}^{*}}\left(\frac{\left[\Pi_{j=1}^{4} g_{t-j+1}^{y *}\right]^{1 / 4}}{e^{\gamma *}}\right)^{\phi_{y}^{*}}\right]^{1-\rho_{R}^{*}} v_{m, t}^{*},
$$

where $g_{t}^{y *}=y_{t}^{*} / y_{t-1}^{*}$ and $v_{m, t}^{*}$ is a short-term interest rate shock following the process,

$$
\log \left(v_{m, t}^{*}\right)=\rho_{m}^{*} \log \left(v_{m, t-1}^{*}\right)+\varepsilon_{m, t}^{*},
$$

where $\varepsilon_{m, t}^{*}$ is an iid shock. As in the home economy, the target inflation rate is time varying and follows the process,

$$
\log \left(\frac{\bar{\pi}_{t}^{*}}{\bar{\pi}^{*}}\right)=\rho_{t p}^{*} \log \left(\frac{\bar{\pi}_{t-1}^{*}}{\bar{\pi}^{*}}\right)+\varepsilon_{t p, t}^{*}
$$


The households in the foreign economy also hold foreign long-term bonds $\left(B_{t}^{L *}\right)$, which are formulated as perpetuities that pay a decaying coupon $\kappa^{s}$ at $t+1+s$. Since the long-term bonds entail a transaction cost $\zeta_{t}^{*}$ per-unit, there exist term premiums as in the home economy. The price and return for the long-term bonds are denoted by $P_{t}^{L *}$ and $R_{t}^{L *}=1 / P_{t}^{L *}+\kappa$, respectively. Note that since foreign households trade only foreign short-term and long-term bonds without paying risk-premium, $\phi$, for the foreign longterm bonds unlike the arbitrager, the hypothetical price of foreign long-term bonds for the arbitrager, $P_{A, t}^{L *}$, is different from that for the foreign households, and their relationship is described as,

$$
\frac{1}{P_{A, t}^{L *}}=\frac{1}{P_{t}^{L *}}+\phi_{t}
$$

That is, to ensure the existence of steady state, the hypothetical price of foreign bonds for the arbitrager is assumed to increase (decrease) relative to that for the foreign households if the net foreign assets held by the arbitrager increase (decrease).

\section{Quantitative Analysis}

In this section, we assume that the home and foreign country in the model correspond to Japan and the United States, respectively, and conduct a quantitative analysis to investigate the inflation rate in Japan as well as the yen-dollar exchange rate dynamics. Since the Japanese economy is modeled as a small open economy, an implicit assumption here is that Japan's economy is influenced by the U.S. economy via the exchange rate and other factors, while the U.S. economy is not affected by Japan's economy. In the quantitative analysis, a particular focus is the effects of short-term interest rate on the inflation rate and the exchange rate through long-term interest rates.

In what follows, we first set the model parameters through calibration and Bayesian estimation using Japanese and U.S. data. In addition, we simulate samples of all variables for 300 quarters based on the estimated model and examine whether our model replicates the important empirical fact that UIP does not hold for short-term yields, but does so for long-term yields. We then quantitatively examine the effect of term premiums using impulse response analysis and show that the model can quantitatively account for 
the salient empirical facts shown in Figure 1. Finally, we decompose developments in Japanese inflation and the yen-dollar exchange rate to understand their dynamics.

\subsection{Estimation}

Before estimating the model parameters, we calibrate some parameter values so that the moment conditions are consistent with Japanese data or simply use conventional values. The quarterly discount factor $\beta$ is set to $1.005^{-\frac{1}{4}}$ for both countries, and the pace of decay for coupons of long-term bonds, $\kappa$, is set to satisfy $1 /(1-\kappa)=40$, which means that it is assumed in this model that the maturity of the long-term bonds is 10 years. The steady state growth rates of productivity, $\gamma=1.01^{\frac{1}{4}}$ and $\gamma^{*}=1.02^{\frac{1}{4}}$, are set to replicate the past performance of the Japanese and U.S. economies. The target inflation rates at the steady state, $\bar{\pi}$ and $\bar{\pi}^{*}$, are set to 1 percent for Japan and 2 percent for the United States based on the past policy conduct of the central banks of the two countries. ${ }^{14}$ The sensitivity of risk premium to the amount of foreign bonds held by the arbitrager is set to an arbitrary small value, $\Phi=0.001$, to minimize its effects on economic dynamics. For the elasticity between domestic and imported consumption goods, $\eta$, we use the value from Bodenstein, Guerrieri and Gust (2013), since no estimates for Japanese households are available. The Calvo parameters, $\xi$, are fixed at 0.8 except for domestic consumption goods, and the markup and indexation rate for wages, $\lambda_{w}$ and $\iota_{w}$, are set to 1.2 and 0.5 , respectively, both of which are conventional values. Finally, (i) the fraction of imported goods in the consumption basket, $\delta$, (ii) the share of imported intermediate goods in the production function, $\alpha$, and (iii) the nominal investment, $I_{d}$, are chosen using the following moments as calibration targets: (i) $P_{f, t} C_{f, t} /\left(P_{t} C_{t}\right)=0.063$, (ii) $P_{f, t} Z_{t} /\left(P_{d, t} Y_{d, t}\right)=0.1$, and (iii) $I_{d} /\left(P_{d, t} Y_{d, t}\right)=0.15$, which are taken from the data for Japan. Table 1 summarizes the calibration values and targets.

The remaining parameters are estimated using the Bayesian approach. In the model,

\footnotetext{
${ }^{14}$ In fact, the Bank of Japan raised its target inflation rate to 2 percent in January 2013, when it formally adopted inflation target policy framework. In quantitative analysis below, that effect should be captured by the target inflation rate shock $\varepsilon_{t p, t}$.
} 
there are 22 parameters for the domestic economy,

$$
\left(\varkappa, \nu, \theta, \zeta, \lambda_{d}, \lambda_{f}, \lambda_{x}, \xi_{d}, \iota_{d}, \iota_{f}, \iota_{x}, \phi_{\pi}, \phi_{y}, \rho_{t p}, \rho_{m}, \rho_{R}, \rho_{\gamma}, \rho_{d}, \rho_{f}, \rho_{x}, \rho_{q}, \rho_{\zeta}\right)
$$

and 11 parameters for the foreign economy,

$$
\left(\varkappa^{*}, \varpi^{*}, \phi_{\pi}^{*}, \phi_{y}^{*}, \zeta^{*}, \rho_{t p}^{*}, \rho_{m}^{*}, \rho_{R}^{*}, \rho_{\gamma}^{*}, \rho_{p}^{*}, \rho_{\zeta}^{*}\right)
$$

Those 33 parameters as well as the variance of the following 14 structural shocks,

$$
\left(\varepsilon_{\gamma}, \varepsilon_{d}, \varepsilon_{f}, \varepsilon_{x}, \varepsilon_{q}, \varepsilon_{\zeta}, \varepsilon_{t p}, \tilde{\varepsilon}_{m}, \hat{\varepsilon}_{m}, \varepsilon_{\gamma}^{*}, \varepsilon_{p}^{*}, \varepsilon_{\zeta}^{*}, \varepsilon_{t p}^{*}, \varepsilon_{m}^{*}\right)
$$

are estimated by the following 12 data sequences in Japan and the U.S.: Japanese GDP growth $(d G D P)$, Japanese core CPI inflation $(d C P I X F V)$, Japanese call rate $(C A L L)$, 3-year Japanese government bond yield (Y12), 10-year Japanese government bond yield ( $Y 40)$, Japanese import price index inflation $(d I P I)$, percent changes in yen-dollar exchange rate $(d F X N)$, Japanese net export-GDP ratio $(r T B)$, the U.S. GDP growth $(d U S G D P)$, the U.S. core CPI inflation $(d U S C P I X F V)$, Federal Funds rate $(F F)$, 10year U.S. government bond yield $(F R)$. Then the measurement equations are formulated as: 


$$
\begin{aligned}
& d G D P=\frac{g d p_{t}}{g d p_{t-1}} e^{\gamma_{t}} \times 100-100 \\
& d C P I X F V=\pi_{t} \times 100-100 \\
& C A L L=\left(R_{t}-1\right) \times 400 \\
& Y 12=\left[\frac{1}{12} E_{t} \sum_{j=1}^{12} R_{t+j-1}-1\right] \times 400 \\
& Y 40=\left(R_{t}^{L}-1\right) \times 400 \\
& d I P I=\pi_{f, t} \times 100-100 \\
& d F X N=\frac{Q_{t}}{Q_{t-1}} \times 100-100 \\
& r T B=\frac{\frac{P_{x, t}^{*}}{P_{t} Q_{t}} Y_{x, t}-\frac{P_{f, t}}{P_{t}} Y_{f, t}}{g d p_{t}} \times 100 \\
& d U S G D P=\frac{y_{t}^{*}}{y_{t-1}^{*}} e^{\gamma_{t}^{*}} \times 100-100 \\
& d U S C P I X F V=\pi_{t}^{*} \times 100-100 \\
& F F=\left(R_{t}^{*}-1\right) \times 400 \\
& F R=\left(R_{t}^{L *}-1\right) \times 400
\end{aligned}
$$

where $g d p_{t} \equiv C_{t}+\frac{I_{d}}{P_{t}}+\frac{P_{x, t}^{*}}{P_{t} Q_{t}} Y_{x, t}-\frac{P_{t}^{*}}{P_{t} Q_{t}} Y_{f, t}$. By simultaneously using the call rate (i.e., the policy rate in Japan), 3-year bond rates, and 10-year bond rates in the measurement equations, the term structure of interest rates is expected to identify the shock to the short-term interest rate $\left(\hat{\varepsilon}_{m}\right)$, the future short-term interest rate $\left(\tilde{\varepsilon}_{t}\right)$, and the term premium $\left(\varepsilon_{\zeta, t}\right)$. In order to exclude the observations that are influenced by the level shift in the yen-dollar exchange rate in the mid 1980s, we use the data from 1987Q1 to 2016 Q3.

Tables 2, 3, and 4 show the prior distribution for estimated parameters and their posterior mean. There are some features to be emphasized. First, we assume a very persistent process with small variance for the target inflation rate as its prior distribution. By doing so, we can can identify the target inflation rate shocks. Second, the estimated variance for the imported price shock $\sigma_{f}$ is large. Since the energy imports has a large 
share in Japanese imports, this large variance of import price shocks seems to reflect large fluctuations in oil prices. ${ }^{15}$ Third, the Calvo parameter for domestic goods $\xi_{d}$ is larger than conventional values. This estimation value probably reflects the fact that Japanese inflation barely changed even with the large fluctuation of imported prices.

\subsection{Simulated Economy and UIP}

We start by investigating whether our model replicates the fact that UIP tends to hold for interest rate differentials over a longer horizon. For this purpose, we simulated samples for 300 quarters based on our estimated model. More concretely, we randomly generated series of 14 structural shocks and calculated the paths of endogenous variables based on the model dynamics for 300 quarters. Based on the simulated data, we calculated the interest rate differentials and nominal exchange rate returns. These are plotted in Figure 4. Figure 4(a) shows that UIP does not hold for policy rate differentials and quarter-onquarter exchange rate returns, since the slope of the regression of changes in the exchange rate on interest rate differentials is much smaller than one. On the other hand, Figure 4(b) showing the relationship between 10-year government bond yields and exchange rate returns over 10 years suggests that UIP holds: the slope is significantly positive and almost one. ${ }^{16}$ This indicates that the assumptions of the limited bond market participation for households and the arbitrager works well as a mechanism to replicate the empirical observation of the relationship between exchange rates and interest rate differentials for short-term and long-term yields.

\footnotetext{
${ }^{15}$ Nominal energy import has a 23 percent share over all nominal imported goods on average from 1987Q1 through 2016Q3. The standard deviation of inflation rates of imported price index for energy is 25 percent during the sample period.

${ }^{16}$ We generated the structural shocks and calculated the paths of the endogenous variables for 300 quarter by repeating the simulation 1,000 times. The average value of the estimated slope of the regression for 10 -year yields is 0.9 , while that for policy rates is 0.2 .
} 


\subsection{Impulse Responses}

In this subsection, we quantitatively examine the effect of changes in term premiums on inflation and the exchange rate. For this purpose, we examine the impulse responses of inflation and the exchange rate to the term premium shock $\varepsilon_{\zeta, t}$. Before conducting the quantitative exercise, we define the term premium using the variables in the model. The first order condition for domestic households with respect to long-term bonds $B_{t}^{L}$ yields

$$
1+\zeta_{t}=\beta E_{t}\left[\frac{\Lambda_{t+1}}{\Lambda_{t} \pi_{t+1}} e^{-\gamma_{t+1}} \frac{P_{t+1}^{L} R_{t+1}^{L}}{P_{t}^{L}}\right],
$$

where $\zeta_{t}$ is the transaction cost incurred when trading long-term bonds. Given that the transaction cost is the only source of the term premium in this model, fictitious long-term interest rates without the term premium, $\tilde{R}_{t}^{L}$, can be computed as follows:

$$
1=\beta E_{t}\left[\frac{\Lambda_{t+1}}{\Lambda_{t} \pi_{t+1}} e^{-\gamma_{t+1}} \frac{\tilde{P}_{t+1}^{L} \tilde{R}_{t+1}^{L}}{\tilde{P}_{t}^{L}}\right],
$$

where $\tilde{R}_{t}^{L}=1 / \tilde{P}_{t}^{L}+\kappa, \tilde{P}_{t}^{L}$ denote the fictitious price of long-term bonds without the term premium, and the term premium is defined by $R_{t}^{L}-\tilde{R}_{t}^{L} \cdot{ }^{17}$ Given this definition of the term premium, the size of term premium shock $\varepsilon_{\zeta, t}$ inducing a one percentage point change in the term premium can be computed.

Figure 5(a) shows the response of the exchange rate to a one percentage point decline in the term premium. The figure indicates that a one percentage point decline in the term premium for 10-year Japanese government bonds leads to a depreciation of the yen versus the dollar of around 10 percent. The mechanism underlying the effect of the term premium on the exchange rates is simple: a decline in the term premium in the home economy caused by a negative shock to $\zeta_{t}$ leads to a decline in the long-term interest rate, $R_{t}^{L}$, and a rise in long-term bond prices, $P_{t}^{L}$, through the Euler equation with respect to long-term bonds for domestic households, Equation (9). The rise in $P_{t}^{L}$ then entails a decline in $Q_{t}$ (i.e., a depreciation of the home country's currency) through the UIP

\footnotetext{
${ }^{17}$ Note that term premiums induced by the covariance term are ignored here, because the model is solved by log-linearization around the steady state, so that any risk premiums induced by the covariance term are zero.
} 
condition (8), which is derived from the optimality condition for the arbitrager. While the size of the impact of the term premium on the exchange rate at first glance seems relatively large, it is consistent with the UIP condition with respect to the long-term interest rate. That is, a one percentage point interest rate differential in 10-year rates across the two countries implies that the return on domestic long-term bonds should be complemented by an appreciation of exchange rate by one percent every year for ten years, which means that the exchange rate should depreciate by 10 percent on impact.

Next, Figure 5(b) shows the response of inflation to a one percentage point decline in the term premium. The figure indicates that a one percentage point decline in term premiums leads to an increase in the inflation rate of around 0.6 percentage points. The upward pressure on inflation in response to the decline in the term premium derives from the depreciation of the nominal exchange rate, $Q_{t}$, through the following two channels. First, the depreciation of the nominal exchange rate increases the marginal costs of imported goods firms, $M C_{f, t}$, and consequently leads to inflationary pressure on the price of imported consumption goods, $P_{f, t}$. The rise in imported goods prices directly raises the price of the consumption basket (i.e., the CPI), because part of the imported goods are consumed by households. Furthermore, since the rest of imported goods are used as intermediate inputs $\left(Z_{t}\right)$ by domestic firms, the rise in imported goods prices also indirectly leads to inflationary pressure on domestic goods prices, $P_{d, t}$, through the rise in marginal costs for domestic firms, $M C_{d, t}$. Second, since the depreciation in $Q_{t}$ represents a decline in marginal costs for exported goods firms, such firms will increase their exports, $Y_{x, t}$, by reducing export prices. Since the increase in exports leads to tightening in the domestic consumption goods market, it pushes up domestic consumption goods prices, $P_{d, t}$. Since the term premium in this model affects the inflation rate only through changes in the exchange rate, all of the changes in the inflation rate in Figure 5(b) stem from changes in the exchange rate. Therefore, the small response of the inflation rate to the large response of the exchange rate indicates that the pass-through rate to the core CPI in Japan is relatively small (around 6 percent on impact). ${ }^{18}$ The impulse responses of the

\footnotetext{
${ }^{18}$ This small pass-through in Japan is, however, consistent with empirical evidence for Japan. See, for example, Burstein and Gopinath (2014) for an extensive survey of pass-through rates in major
} 
inflation and exchange rates to a decline in the term premium are in line with the recent experiences in Japan: while the yen has depreciated by more than 20 percent vis-à-vis the U.S. dollar since 2013, the increase in core inflation in Japan has been relatively small. ${ }^{19}$ We will investigate this point in more detail in the next subsection.

While the mechanism underlying the effect of the term premium seems intuitive and straightforward, the term premium does not have any effect without the limited bond market participation assumptions for households and the arbitrager in our model. ${ }^{20}$ To see this, let us imagine an economy where households can access foreign bonds and consequently UIP is also satisfied with respect to short-term interest rates. In such an alternative economy, the first order conditions with respect to domestic short-term and long-term bonds as well as short-term foreign bonds provide the following three Euler equations for domestic households:

$$
\begin{aligned}
1 & =\beta R_{t} E_{t}\left[\frac{\Lambda_{t+1}}{\Lambda_{t} \pi_{t+1}} e^{-\gamma_{t+1}}\right] \\
1+\zeta_{t} & =\beta E_{t}\left[\frac{\Lambda_{t+1}}{\Lambda_{t} \pi_{t+1}} e^{-\gamma_{t+1}} \frac{P_{t+1}^{L} R_{t+1}^{L}}{P_{t}^{L}}\right],
\end{aligned}
$$

and

$$
1=\beta R_{t}^{*} E_{t}\left[\frac{\Lambda_{t+1}}{\Lambda_{t} \pi_{t+1}} e^{-\gamma_{t+1}} \frac{Q_{t}}{Q_{t+1}}\right] .
$$

Suppose that the term premium drops due to a negative shock to the transaction cost, $\zeta_{t}$. Equation (11) implies that prices of long-term bonds $P_{t}^{L}$ would rise (i.e., long-term interest rates $R_{t}^{L}$ would decline) in response to the decline in $\zeta_{t}$. Equation (10) indicates, however, that the stochastic discount factor $\beta\left[\frac{\Lambda_{t+1}}{\Lambda_{t} \pi_{t+1}} e^{-\gamma_{t+1}}\right]$ would not respond to the change in $\zeta_{t}$ at all and would not change as long as short-term interest rates $R_{t}$ do not change. Therefore, if the covariance term is ignored, equation (12) implies that the nominal exchange rate $Q_{t}$ does not respond at all to the decline in $\zeta_{t}$ or the ensuing decline

economies, including Japan.

${ }^{19}$ Core inflation reached about 1.4 percent in 2014Q2 compared to about -0.3 percent in 2013Q1.

${ }^{20}$ Although this feature of our model is common in a stylized DSGE model, it might be considered too restrictive. As pointed out by Bank of Japan (2016), a decline in long-term bond yields can affect the real economy through other channels by assuming that some parts of households or firms have access only to long-term bonds. 
in $R_{t}^{L} \cdot{ }^{21}$ In other words, without the limited bond market participation assumptions for households and the arbitrager, the change in the term premium caused by a shock to $\zeta_{t}$ would be just a "sideshow" for the real economy and inflation in this alternative economy. This can be understood as being in line with the finding of Chen, Cúrdia and Ferrero (2012). As they point out, changes in term premiums do not have any effect on the economy unless there is an agent who only has access to long-term bonds and whose actions are relevant to the economy. In our model, the domestic arbitrager, who trades only domestic and foreign long-term bonds, takes this role. The arbitrager's actions are relevant to the economy because the limited bond market participation assumption for households implies that only the arbitrager's actions determine the exchange rate. In their model, on the other hand, the fraction of households that do not have access to short-term bonds (and thus borrow and lend only through long-term bonds) take this role. As shown by our model, without this limited participation assumption for a fraction of households, term premiums would not have any effect on inflation and the real economy in their model.

\subsection{Decomposition of Long-term Yields, the Exchange Rate, and the Inflation Rate}

In order to examine the determinants of recent economic developments in Japan, we decompose changes in long-term bond yields, the nominal exchange rate, and the inflation rate into the contribution of different factors. Specifically, we focus on five different types of factors, namely, domestic term premium shock $\left(\epsilon_{\zeta}\right)$, domestic trend inflation shock $\left(\epsilon_{t p}\right)$, domestic short-term interest rate factors $\left(\hat{\epsilon}_{m}\right.$ and $\left.\tilde{\epsilon}_{m}\right)$, foreign factors $\left(\epsilon_{x}, \epsilon_{f}, \epsilon_{q}, \epsilon_{m}^{*}, \epsilon_{\gamma}^{*}, \epsilon_{p}^{*}, \epsilon_{t p}^{*}\right.$ and $\left.\epsilon_{\zeta}^{*}\right)$, and domestic and other factors $\left(\epsilon_{\gamma}, \epsilon_{d}\right.$, and initial values). Among these different types of shocks, we particularly focus on the extent to which domestic term premium shocks explain developments in the inflation rate in Japan over the last decade, since we assume here that they represent the effects of QQE.

\footnotetext{
${ }^{21}$ Although the analysis is not shown here, if the arbitrager had access to short-term bonds in addition to long-term bonds, changes in term premiums would have no effect on the exchange rate.
} 
The decomposition of changes in historical long-term bond yields shows that it has been heavily affected by both domestic and foreign factors. Figure 6 presents the decomposition of the cumulative change in 10-year bond yields from 2007 to the present. The figure indicates that the decline in long-term bond yields since 2013 is mostly accounted for by the decline in the term premium (which is responsible for -0.5 percentage points out of the total decline in long-term bonds yields of -0.8 percentage points). However, it should be noted that not only the domestic term premium, but also foreign factorsin particular U.S. term premium shocks - made a major contribution to the decline in Japanese long-term yields. U.S. long-term yields declined substantially during and after the global financial crisis, reflecting the decline in the term premium under the quantitative easing policy pursued by the Federal Reserve. The mechanism through which the decline in the U.S. term premium affects Japanese long-term yields is as follows. The decline in the U.S. term premium leads to a depreciation of the U.S. dollar versus the yen, which in turn exerts deflationary pressure in Japan and pulls down expected short-term rates, leading to a reduction in Japanese long-term yields.

Next, the decomposition of changes in the nominal exchange rate indicates that developments in Japanese long-term yields as well as foreign factors have a substantial impact on the U.S. yen-dollar exchange rate through UIP for long-term yields. Figure 7 (a) shows the decomposition of cumulative changes in the yen-dollar exchange rate from 2007. The figure shows that term premium shocks made a sizable contribution to the depreciation of the Japanese yen, particularly from 2013 to the present (accounting for -5.4 percentage points out of -12.6 percentage points), which implies that QQE decreased long-term bond yields and consequently affected the exchange rate. Nevertheless, as can also be seen in the figure, foreign factors were the main driver of changes in the yen-dollar exchange rate: most of the depreciation of the yen from 2013 until the middle of 2015 is accounted for by changes in foreign factors $(-24.0$ percentage points out of -28.8 percentage points). That is, while both foreign factors as well as domestic term premiums and short-term interest rate shocks exerted downward pressure on the yen simultaneously, foreign factors accounted for most of the depreciation of the yen of 
more than 20 percent observed after the introduction of QQE. ${ }^{22}$

To examine the large contributions of foreign factors in exchange rate dynamics in more detail, Figure 7(b) provides a breakdown of the contribution of various components. As can be seen in the figure, the main driver of nominal exchange rate dynamics is changes in the U.S. term premium, which drove down long-term rates substantially. The decline exerted upward pressure on the yen vis-à-vis the U.S. dollar until 2013. In the second half of 2013, expectations were rising that the Fed would start tapering its long-term bond purchases, which coincides with the time when upward pressure on the yen diminished substantially. From the end of 2015, the yen started to appreciate again because of foreign factors including U.S. term premium shocks: long-term bond yields in the United States had stopped increasing, reflecting partly the change in market participants' views about the pace at which Fed would raise its policy rate. ${ }^{23}$

We should also note that downward pressure on the yen from trade balance shocks intensified from 2012 and reached its peak in 2014. This likely reflects the huge trade deficit due to the increase in energy imports after the Great East Japan Earthquake. However, since 2014, such downward pressure from the trade balance has stopped intensifying, partly due to the reduction in Japan's dependence on imported energy.

Finally, the decomposition of changes in CPI inflation indicates that both term premium shocks and short-term interest rate shocks helped to push up inflation in Japan. Figure $8(\mathrm{a})$ indicates that the positive contribution of term premium shocks to CPI inflation increased gradually from 2009, although the magnitude of the contribution was

\footnotetext{
${ }^{22}$ The large effects of foreign factors on recent exchange dynamics are consistent with the findings of other empirical studies such as Kano and Wada (2017).

${ }^{23}$ Changes in market participants' views regarding the pace of policy rate hikes by the Fed can also be gleaned from the Federal Funds (FF) futures rate. For example, at the end of 2015, the FF futures rate for the December 2016 Federal Open Market Committee meeting was 0.9 percent, but it declined to 0.5 percent at the end of September 2016. Because we did not include interest rate news shocks for the United State and the U.S. economy is described as a small scale New Keynesian model, the fluctuations in the 10-year U.S. government bond yield are mainly explained by the term premium shock as a residual. See, for example, Rudebusch and Swanson (2008) for more detailed discussion of the difficulty of explaining the fluctuations in long-term yields by DSGE models.
} 
relatively modest (about 0.4 percentage points). On the other hand, the contribution of anticipated and unanticipated short-term interest rate shocks increased from 2013, with short-term interest rate shocks raising the inflation rate by about 0.8 percentage points. Even though short- and medium-term interest rates did not change substantially, shortterm interest rate shocks did make a substantial contribution to the increase in inflation since 2013 because they reflect the Bank of Japan's policy stance that it would not increase its policy rate in response to modest inflation. That is, the positive contribution of short-term interest rate shocks can be interpreted as the positive effect of the Bank of Japan's commitment to keep interest rates low to achieve the target inflation level.

However, while domestic short-term interest rate shocks and term premium shocks exerted upward pressure on inflation in Japan, foreign factors, which include imported good marginal cost shocks, U.S. short-term interest rate shocks, and term premium shocks exerted considerable downward pressure on inflation after 2015, pushing inflation back into negative territory. Figure 8(a) suggests that the magnitude of the negative contribution of foreign factors is comparable to that in 2009, when the Japanese economy was hit by unprecedented adverse shocks in the wake of the global financial crisis. This result highlights that Japanese inflation rates are highly susceptible to foreign shocks, which are completely exogenous for the Japanese economy in this model. Figure 8(b) provides details on the contribution of foreign factors to Japanese CPI inflation rates. The figure shows that while foreign financial factors such as U.S. term premium gradually exerted downward pressure on inflation in Japan, the foreign factor that exerted the greatest downward pressure since 2015 is the cost of imported goods. Given the substantial decline in energy prices since 2015, Figure 8(b) suggests that the decline in the price of imports due to the drop in energy prices was the main factor pushing down Japan's inflation rate since $2015 .^{24}$

To sum up, the combination of term premium and short-term interest rate shocks resulting from Bank of Japan monetary policy substantially influenced inflation and generated inflationary pressure from 2013 onward, adding about 1 percentage point to

\footnotetext{
${ }^{24}$ The import price index for petroleum, coal, and natural gas, for instance, fell by 44 percent from December 2014 through September 2016.
} 
the inflation rate. Furthermore, we find that foreign factors, in particular the decrease in the U.S. term premium and its effects through the exchange rate, play an important role in explaining developments in Japanese long-term interest rates, the yen-dollar exchange rate, and the inflation rate.

\section{Conclusion}

This paper explored the possibility that term premiums influence the economy via exchange rate dynamics, focusing in particular on the fact that UIP tends to hold for longer term interest rate differentials. We constructed a small-open economy model with limited asset market participation assumptions of households, and estimated the parameters using data for Japan and the United States. The quantitative exercise using impulse response analysis showed that changes in the term premium have sizable effects on the inflation rate as well as on the exchange rate. Furthermore, the decomposition of developments in the CPI inflation rate showed that term premium shocks contributed 0.4 percentage points to the increase in the inflation rate in 2013 and 2014, when the CPI increased substantially. Finally, we found that Japan's inflation rates are heavily affected by foreign factors, especially by U.S. term premium shocks through the exchange rate dynamics.

To deepen the study on term premiums, our analysis can be extended by explicitly modeling term premiums as Rudebusch and Swanson (2012) suggested using a higherorder approximation method. In addition, given the fact that Japanese short-term rates have been almost zero for these two decades, incorporating a zero lower bound in a smallopen model would help us to further understand the relationship among term premiums, inflation rates, and exchange rates.

\section{References}

Adolfson, Malin, Stefan Laséen, Jesper Lindé, and Mattias Villani. 2007. "Bayesian estimation of an open economy DSGE model with incomplete pass- 
through." Journal of International Economics, 72(2): 481-511.

Adolfson, Malin, Stefan Laséen, Jesper Lindé, and Mattias Villani. 2008. "Evaluating an estimated new Keynesian small open economy model." Journal of Economic Dynamics and Control, 32(8): 2690-2721.

Alpanda, Sami, and Serdar Kabaca. 2015. "International spillovers of large-scale asset purchases." Bank of Canada Staff Working Paper No.2015-2.

Andrés, Javier, J David López-Salido, and Edward Nelson. 2004. "Tobin's imperfect asset substitution in optimizing general equilibrium." Journal of Money, Credit, and Banking, 36(4): 665-690.

Aoki, Kosuke, Alexander Michaelides, and Kalin Nikolov. 2016. "Household portfolios in a secular stagnation world: Evidence from Japan." Bank of Japan Working Paper Series No.16-E-4.

Bank of Japan. 2016. "Comprehensive assessment: Developments in economic activity and prices as well as policy effects since the introduction of quantitative and qualitative monetary easing (QQE), the background." Attachment 1 on the statement of the monetary policy meeting held on September 20 and 21, 2016.

Bank of Japan, Monetary Affairs Department. 2015. "Quantitative and qualitative monetary easing: Assessment of its effects in the two years since its introduction." Bank of Japan Review Series 15-E-3.

Bodenstein, Martin, Luca Guerrieri, and Christopher J Gust. 2013. "Oil shocks and the zero bound on nominal interest rates." Journal of International Money and Finance, 32: 941-967.

Burstein, Ariel, and Gita Gopinath. 2014. "International prices and exchange rates." Handbook of International Economics, 4: 391-451.

Calvo, Guillermo A. 1983. "Staggered prices in a utility-maximizing framework." Journal of Monetary Economics, 12(3): 383-398. 
Chen, Han, Vasco Cúrdia, and Andrea Ferrero. 2012. "The macroeconomic effects of large-scale asset purchase programmes." The Economic Journal, 122(564): 289-315.

Chinn, Menzie D. 2006. "The (partial) rehabilitation of interest rate parity in the floating rate era: Longer horizons, alternative expectations, and emerging markets." Journal of International Money and Finance, 25(1): 7-21.

Chinn, Menzie D, and Guy Meredith. 2004. "Monetary policy and long-horizon uncovered interest parity." IMF Economic Review, 51(3): 409-430.

Chodorow-Reich, Gabriel. 2014. "Effects of unconventional monetary policy on financial institutions." Brookings Papers on Economic Activity, Spring 2014(1): 155-227.

Coeurdacier, Nicolas, and Helene Rey. 2013. "Home bias in open economy financial macroeconomics." Journal of Economic Literature, 51(1): 63-115.

Curdia, Vasco, and Michael Woodford. 2011. "The central-bank balance sheet as an instrument of monetarypolicy." Journal of Monetary Economics, 58(1): 54-79.

D’Amico, Stefania, William English, David López-Salido, and Edward Nelson. 2012. "The Federal Reserve's large-scale asset purchase programmes: Rationale and effects." The Economic Journal, 122(564): 415-446.

Engel, Charles. 2014. "Exchange rates and interest parity." Handbook of International Economics, 4: 453-522.

Fama, Eugene F. 1970. "Efficient capital markets: A review of theory and empirical work." The Journal of Finance, 25(2): 383-417.

Faust, Jon. 2015. "Did we avoid 'it'? and other mid-recovery questions." Bank of Canada Working Papers 2015-2.

French, Kenneth R, and James Michael Poterba. 1991. "Investor diversification and international equity markets." The American Economic Review, 81(2): 222-226. 
Fujiki, Hiroshi, Naohisa Hirakata, and Etsuro Shioji. 2012. "Aging and household stockholdings: Evidence from Japanese household survey data." IMES Discussion Paper No. 2012-E-17.

Gertler, Mark, and Nobuhiro Kiyotaki. 2010. "Financial intermediation and credit policy in business cycle analysis." Handbook of Monetary Economics, 3(3): 547-599.

Gertler, Mark, and Peter Karadi. 2011. "A model of unconventional monetary policy." Journal of Monetary Economics, 58(1): 17-34.

Hanson, Samuel G, and Jeremy C Stein. 2015. "Monetary policy and long-term real rates." Journal of Financial Economics, 115(3): 429-448.

Joyce, Michael, David Miles, Andrew Scott, and Dimitri Vayanos. 2012. "Quantitative easing and unconventional monetary policy-An introduction." The Economic Journal, 122(564): F271-F288.

Kano, Takashi, and Kenji Wada. 2017. "The first arrow hitting the currency target: A long-run risk perspective." Journal of International Money and Finance, , (74): 337352.

Kinari, Yusuke, and Yoshiro Tsutsui. 2009. "Determinants of share of risky assets in Japan." Review of Monetary and Financial Studies (in Japanese), 29: 46-65.

Milani, Fabio, and John Treadwell. 2012. "The effects of monetary policy 'news' and 'surprises'." Journal of Money, Credit and Banking, 44(8): 1667-1692.

Modigliani, Franco, and Richard Sutch. 1966. "Innovations in interest rate policy." The American Economic Review, 56(1/2): 178-197.

Rudebusch, Glenn D, and Eric T Swanson. 2008. "Examining the bond premium puzzle with a DSGE model." Journal of monetary Economics, 55: S111-S126.

Rudebusch, Glenn D, and Eric T Swanson. 2012. "The bond premium in a DSGE model with long-run real and nominal risks." American Economic Journal: Macroeconomics, 4(1): 105-143. 
Schmitt-Grohé, Stephanie, and Martın Uribe. 2003. "Closing small open economy models." Journal of International Economics, 61(1): 163-185.

Stein, Jeremy C. 2012. "Evaluating large-scale asset purchases : A speech at the Brookings Institution, October 11, 2012." Speech, Board of Governors of the Federal Reserve System (U.S.).

Tobin, James. 1961. "Money, capital, and other stores of value." The American Economic Review, 51(2): 26-37.

Tobin, James. 1963. An essay on the principles of debt management. Cowles Foundation for Research in Economics at Yale University.

Tobin, James. 1969. "A general equilibrium approach to monetary theory." Journal of Money, Credit and Banking, 1(1): 15-29.

Ugai, Hiroshi. 2007. "Effects of the quantitative easing policy: A survey of empirical analyses." Monetary and Economic Studies, 25(1): 1-47.

Vayanos, Dimitri, and Jean-Luc Vila. 2009. "A preferred-habitat model of the term structure of interest rates." NBER Working Paper No.15487.

Wesolowski, Grzegorz. 2016. "Do long term interest rates drive GDP and inflation in small open economies? Evidence from Poland." NBP Working Paper No.242.

Woodford, Micheal. 2001. "Fiscal requirements for price stability." Journal of Money, Credit and Banking, 33(3): 669-669. 
Table 1: Calibration

\begin{tabular}{lc}
\hline Parameter & Value or target \\
\hline \hline Discount factor, $\beta$ and $\beta^{*}$ & 0.998 \\
Decaying coupon, $\kappa$ & $1-\frac{1}{40}$ \\
Productivity growth (Japan $\gamma$ and the U.S. $\left.\gamma^{*}\right)$ & $1.01^{\frac{1}{4}}$ and $1.02^{\frac{1}{4}}$ \\
Target inflation rate (Japan $\bar{\pi}$ and the U.S. $\left.\bar{\pi}^{*}\right)$ & $1.01^{\frac{1}{4}}$ and $1.02^{\frac{1}{4}}$ \\
Sensitivity of risk premium, $\Phi$ & 0.001 \\
Elasticity between domestic and foreign goods, $\eta$ & 1.076 \\
Calvo parameter, $\xi_{w}, \xi_{f}$, and $\xi_{x}$, & 0.8 \\
Wage markup, $\lambda_{w}$ & 1.2 \\
Wage indexation, $\iota_{w}$ & 0.5 \\
Share of imported consumption goods, $\delta$ & $P_{f, t} C_{f, t} /\left(P_{t} C_{t}\right)=0.063$ \\
Share of imported intermediate goods, $\alpha$ & $P_{f, t} Z_{t} /\left(P_{d, t} Y_{d, t}\right)=0.1$ \\
Nominal investment, $I_{d}$ & $I_{d} /\left(P_{d, t} Y_{d, t}\right)=0.15$ \\
\hline
\end{tabular}


Table 2: Parameter Values for Japan

\begin{tabular}{|c|c|c|c|c|}
\hline parameter & posterior mean & prior dist. & prior mean & prior stdev \\
\hline$\varkappa$ & 0.37 & Beta & 0.4 & 0.1 \\
\hline$\nu$ & 1.14 & Gamma & 1.0 & 0.5 \\
\hline$\theta$ & 1.16 & Gamma & 1.0 & 0.5 \\
\hline$\zeta$ & 0.0019 & Beta & 0.01 & 0.005 \\
\hline$\lambda_{d}$ & 2.29 & Gamma & 1.2 & 0.5 \\
\hline$\lambda_{f}$ & 3.39 & Gamma & 1.2 & 0.5 \\
\hline$\lambda_{x}$ & 2.04 & Gamma & 1.2 & 0.5 \\
\hline$\xi_{d}$ & 0.95 & Beta & 0.66 & 0.1 \\
\hline$\iota_{d}$ & 0.12 & Beta & 0.5 & 0.2 \\
\hline$\iota_{f}$ & 0.13 & Beta & 0.5 & 0.2 \\
\hline$\iota_{x}$ & 0.47 & Beta & 0.5 & 0.2 \\
\hline$\phi_{\pi}$ & 0.32 & Gamma & 0.5 & 0.25 \\
\hline$\phi_{y}$ & 0.19 & Gamma & 0.5 & 0.15 \\
\hline$\rho_{t p}$ & 0.99 & Beta & 0.97 & 0.02 \\
\hline$\rho_{m}$ & 0.68 & Beta & 0.5 & 0.2 \\
\hline$\rho_{R}$ & 0.87 & Beta & 0.8 & 0.05 \\
\hline$\rho_{\gamma}$ & 0.66 & Beta & 0.5 & 0.2 \\
\hline$\rho_{d}$ & 0.19 & Beta & 0.5 & 0.2 \\
\hline$\rho_{f}$ & 0.92 & Beta & 0.5 & 0.2 \\
\hline$\rho_{x}$ & 0.92 & Beta & 0.5 & 0.2 \\
\hline$\rho_{q}$ & 0.88 & Beta & 0.5 & 0.2 \\
\hline$\rho_{\varsigma}$ & 0.93 & Beta & 0.5 & 0.2 \\
\hline
\end{tabular}


Table 3: Parameter Values for the U.S.

\begin{tabular}{ccccc}
\hline parameter & posterior mean & prior dist. & prior mean & prior stdev \\
\hline \hline$\varkappa^{*}$ & 0.36 & Beta & 0.4 & 0.1 \\
$\varpi^{*}$ & 0.009 & Beta & 0.1 & 0.05 \\
$\phi_{\pi}^{*}$ & 1.55 & Gamma & 0.5 & 0.2 \\
$\phi_{y}^{*}$ & 1.10 & Gamma & 0.5 & 0.2 \\
$\zeta^{*}$ & 0.0054 & Beta & 0.016 & 0.008 \\
$\rho_{t p}^{*}$ & 0.99 & Beta & 0.97 & 0.02 \\
$\rho_{m}^{*}$ & 0.60 & Beta & 0.5 & 0.2 \\
$\rho_{R}^{*}$ & 0.72 & Beta & 0.8 & 0.1 \\
$\rho_{\gamma}^{*}$ & 0.96 & Beta & 0.5 & 0.2 \\
$\rho_{p}^{*}$ & 0.39 & Beta & 0.5 & 0.2 \\
$\rho_{\zeta}^{*}$ & 0.97 & Beta & 0.5 & 0.2 \\
\hline
\end{tabular}

Table 4: Parameter Values for Standard Deviation

\begin{tabular}{ccccc}
\hline parameter & posterior mean & prior dist. & prior mean & prior stdev \\
\hline \hline$\sigma_{\gamma}$ & 0.76 & Inv. Gamma & 0.50 & inf. \\
$\sigma_{d}$ & 54.10 & Inv. Gamma & 0.50 & inf. \\
$\sigma_{f}$ & 4.56 & Inv. Gamma & 0.50 & inf. \\
$\sigma_{x}$ & 0.13 & Inv. Gamma & 0.50 & inf. \\
$\sigma_{q}$ & 0.16 & Inv. Gamma & 0.50 & inf. \\
$\sigma_{\zeta}$ & 0.15 & Inv. Gamma & 0.25 & inf. \\
$\sigma_{t p}$ & 0.02 & Inv. Gamma & 0.05 & inf. \\
$\tilde{\sigma}_{m}$ & 0.07 & Inv. Gamma & 0.50 & inf. \\
$\hat{\sigma}_{m 12}$ & 0.05 & Inv. Gamma & 0.25 & inf. \\
$\sigma_{\gamma}^{*}$ & 0.17 & Inv. Gamma & 0.50 & inf. \\
$\sigma_{p}^{*}$ & 0.10 & Inv. Gamma & 0.50 & inf. \\
$\sigma_{\zeta}^{*}$ & 0.13 & Inv. Gamma & 0.25 & inf. \\
$\sigma_{t p}^{*}$ & 0.03 & Inv. Gamma & 0.05 & inf. \\
$\sigma_{m}^{*}$ & 0.10 & Inv. Gamma & 0.75 & inf. \\
\hline
\end{tabular}


Figure 1: Interest Rate Differentials and Exchange Rate Dynamics

(a) Policy Rates (Overnight Rates)

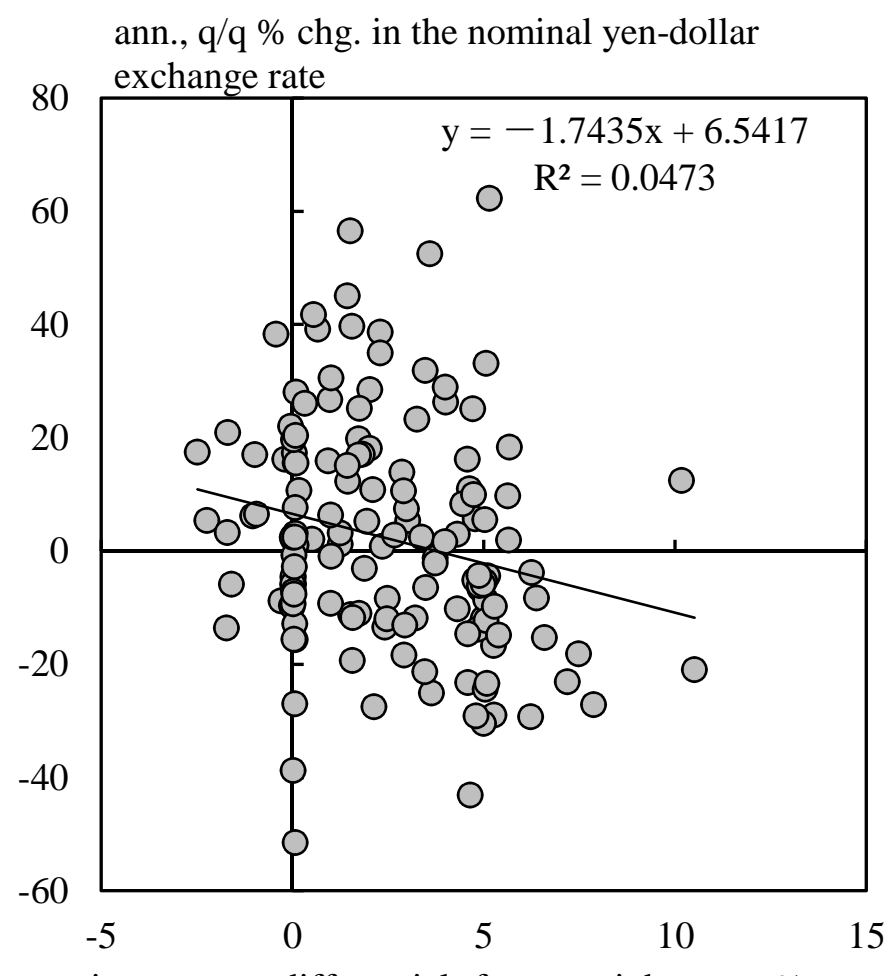

interest rate differentials for overnight rates, \%

(c) 5-year Bond Yields

ann., \% chg. in the nominal yen-dollar exchange

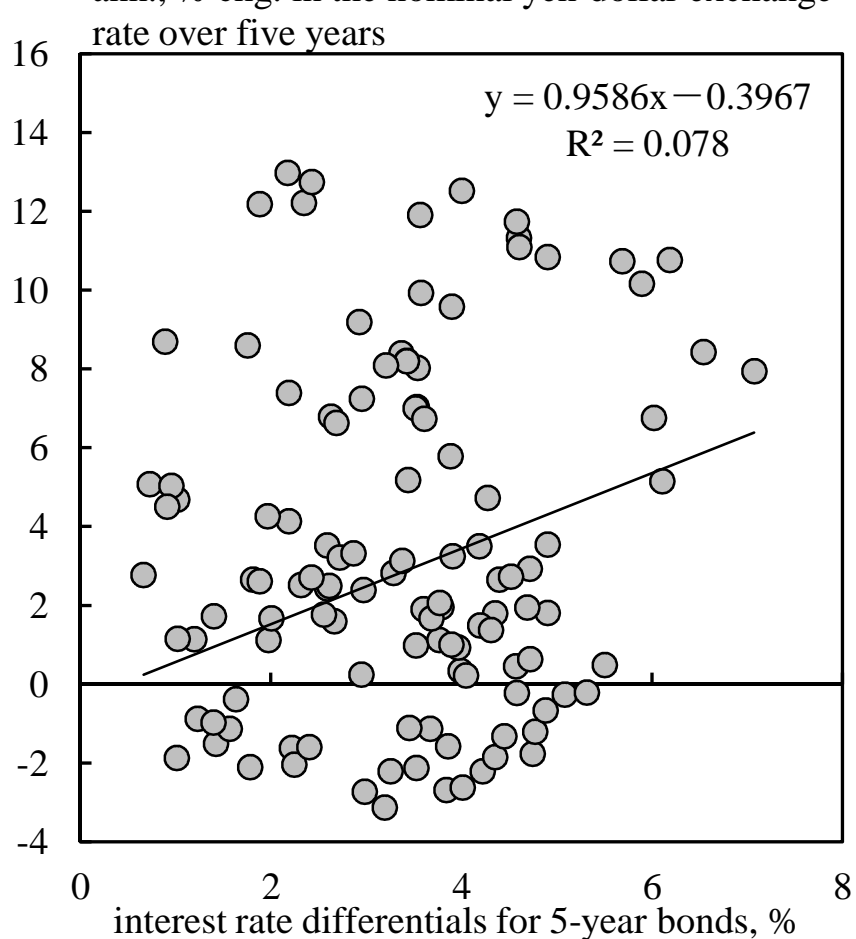

(b) 2-year Bond Yields

ann., \% chg. in the nominal yen-dollar exchange

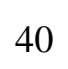

rate over two years

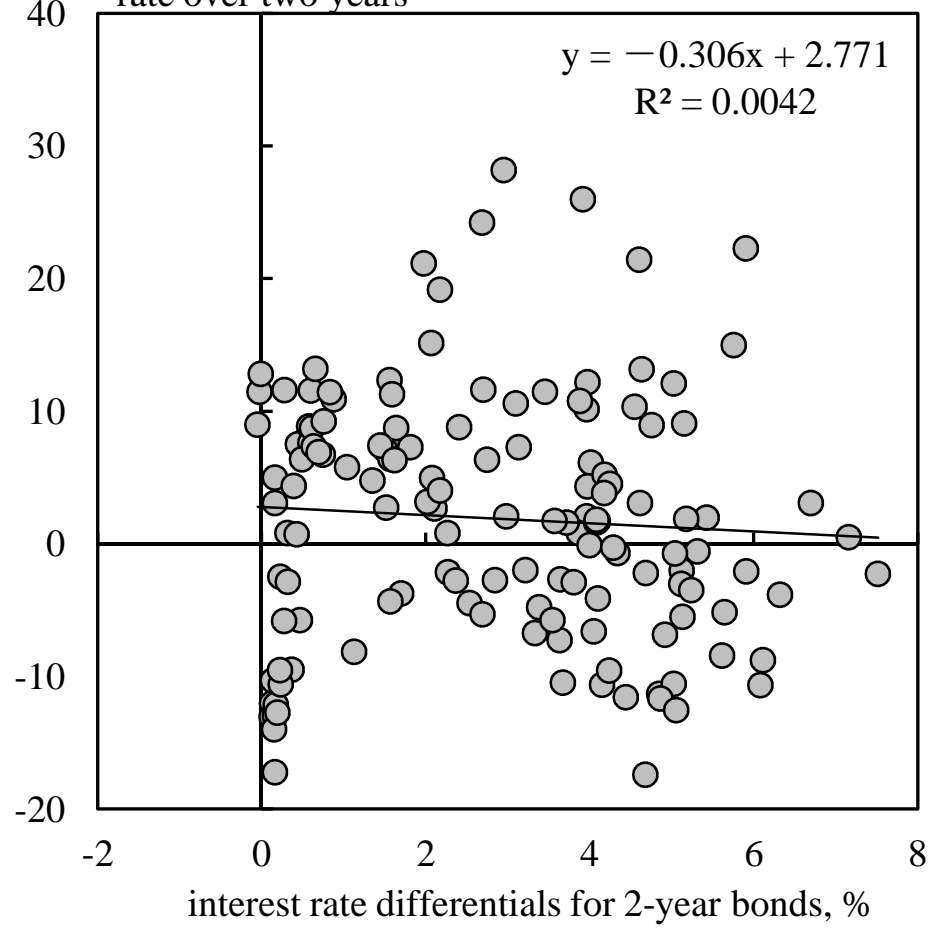

(d) 10-year Bond Yields

ann., \% chg. in the nominal yen-dollar exchange rate over 10 years

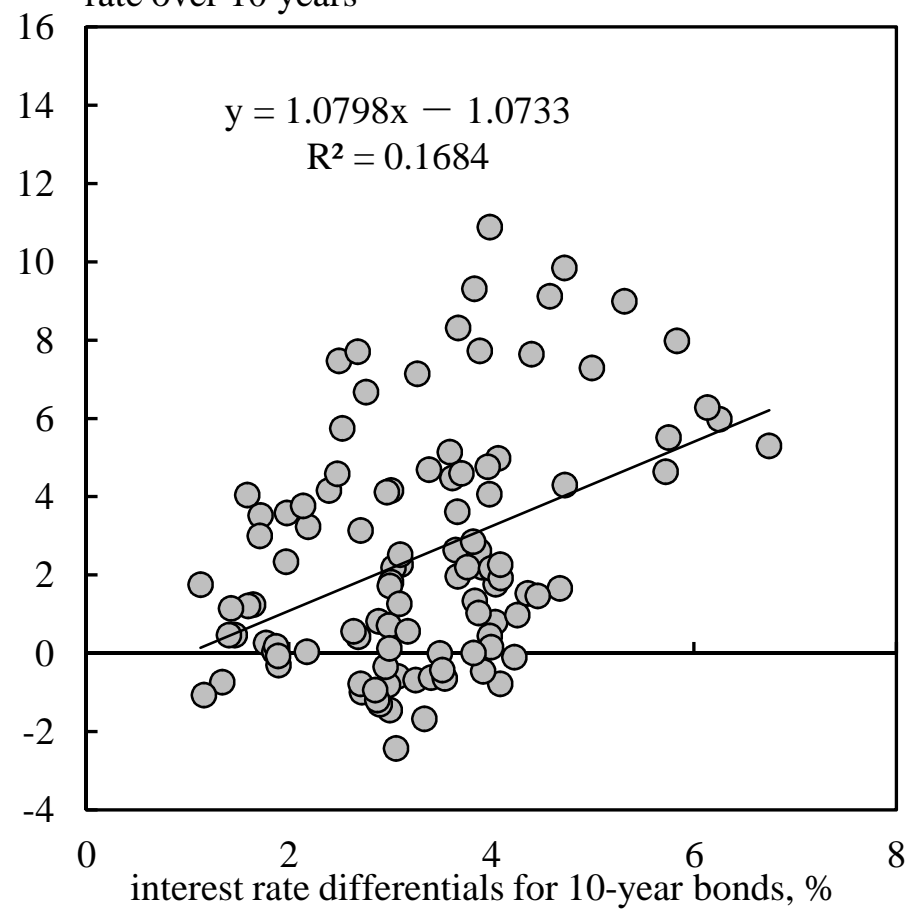

Notes: 1 . The figures show interest rate differentials between $n$-year government bond yields in the U.S. and Japan at time $t$, and the yen-dollar exchange rate return from $t$ to $t+n$ based on the data from 1987Q1 through $2016 \mathrm{Q} 3$.

2. A positive exchange rate return indicates an appreciation of the yen against the U.S. dollar.

3. The interest rate differentials are calculated by subtracting interest rates in Japan from those in the U.S. 
Figure 2: Composition of Japanese Household Assets

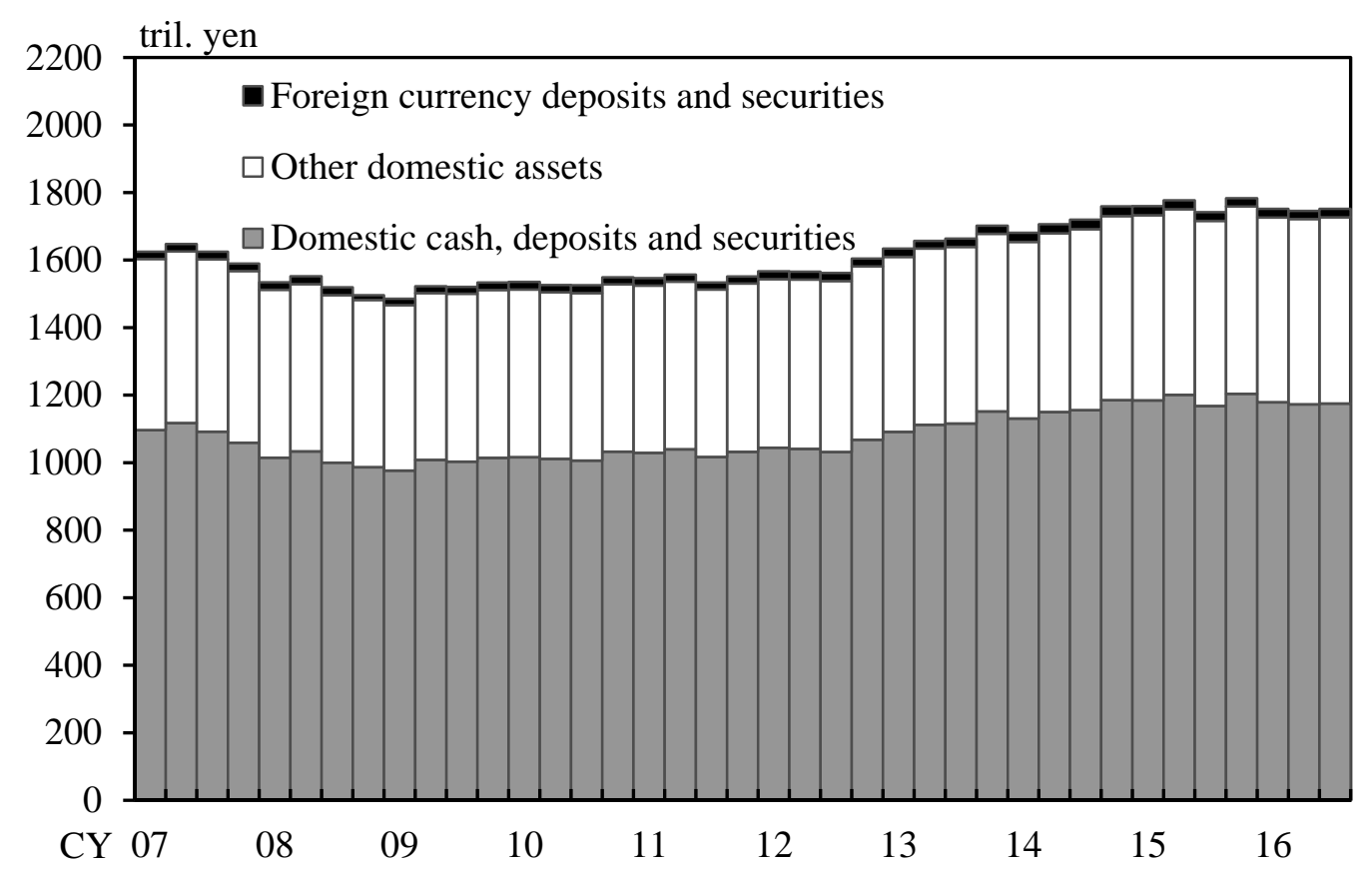

Source: Bank of Japan, "Flow of Funds." 
Figure 3: Domestic Government Bond and Foreign Debt Security Holdings of Japanese Institutional Investors

(a) Domestic Government Bonds

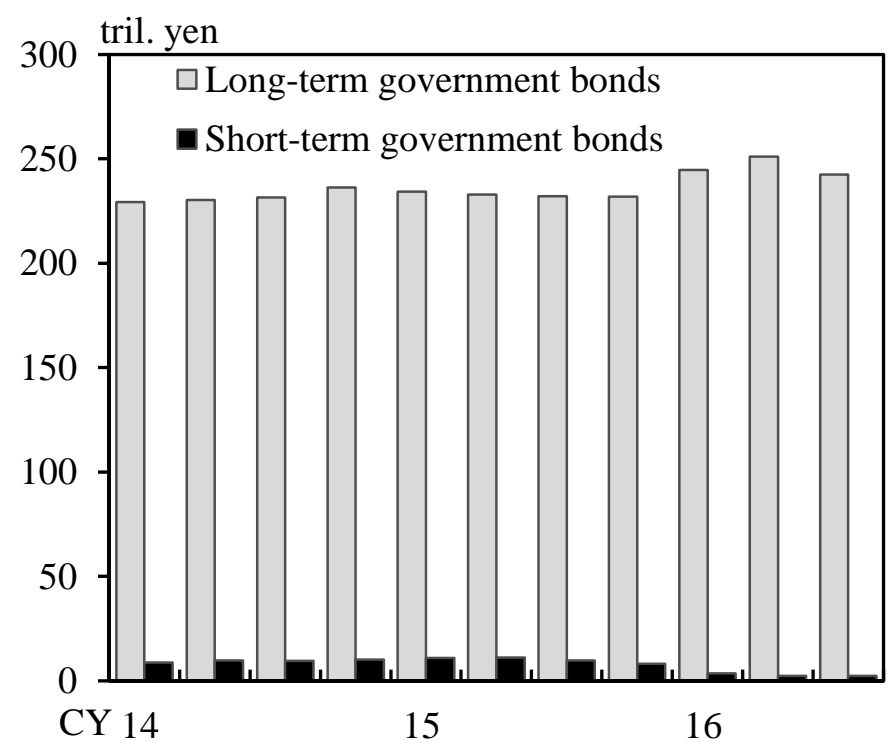

(b) Foreign Debt Securities

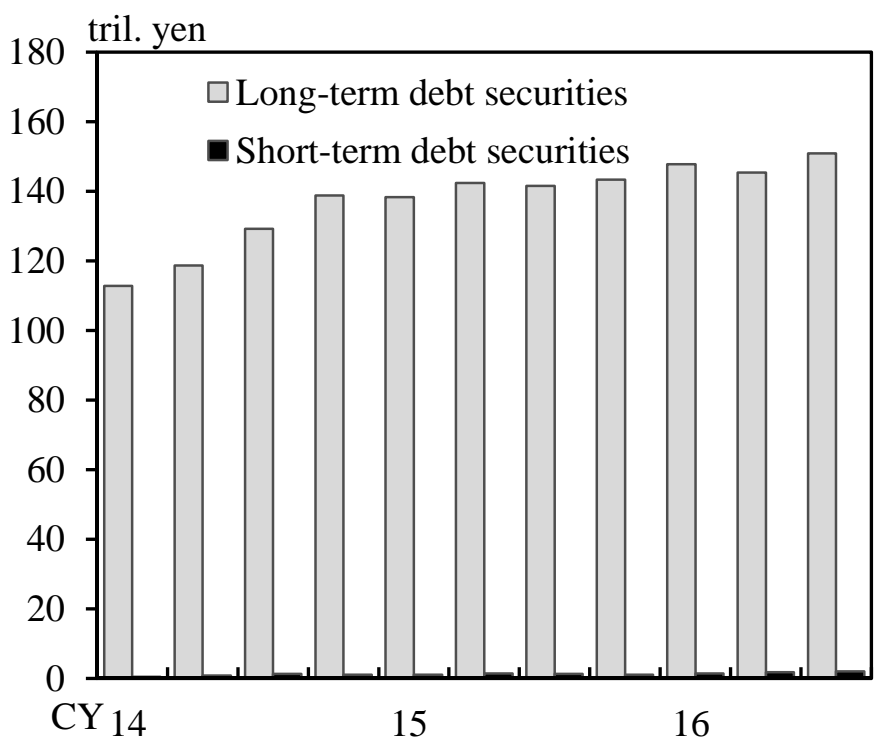

Notes: 1. Japanese institutional investor consists of bond investments trusts, and insurance and pension funds.

2. Long-term domestic government bonds are composed of central government securities and fiscal investment and local program bonds.

Sources: Bank of Japan, "Flow of Funds"; Ministry of Finance, "International Investment Position." 
Figure 4: Interest Rate Differentials and Exchange Rate Dynamics for Simulated Data

(a) Policy Rates (Overnight Rates)

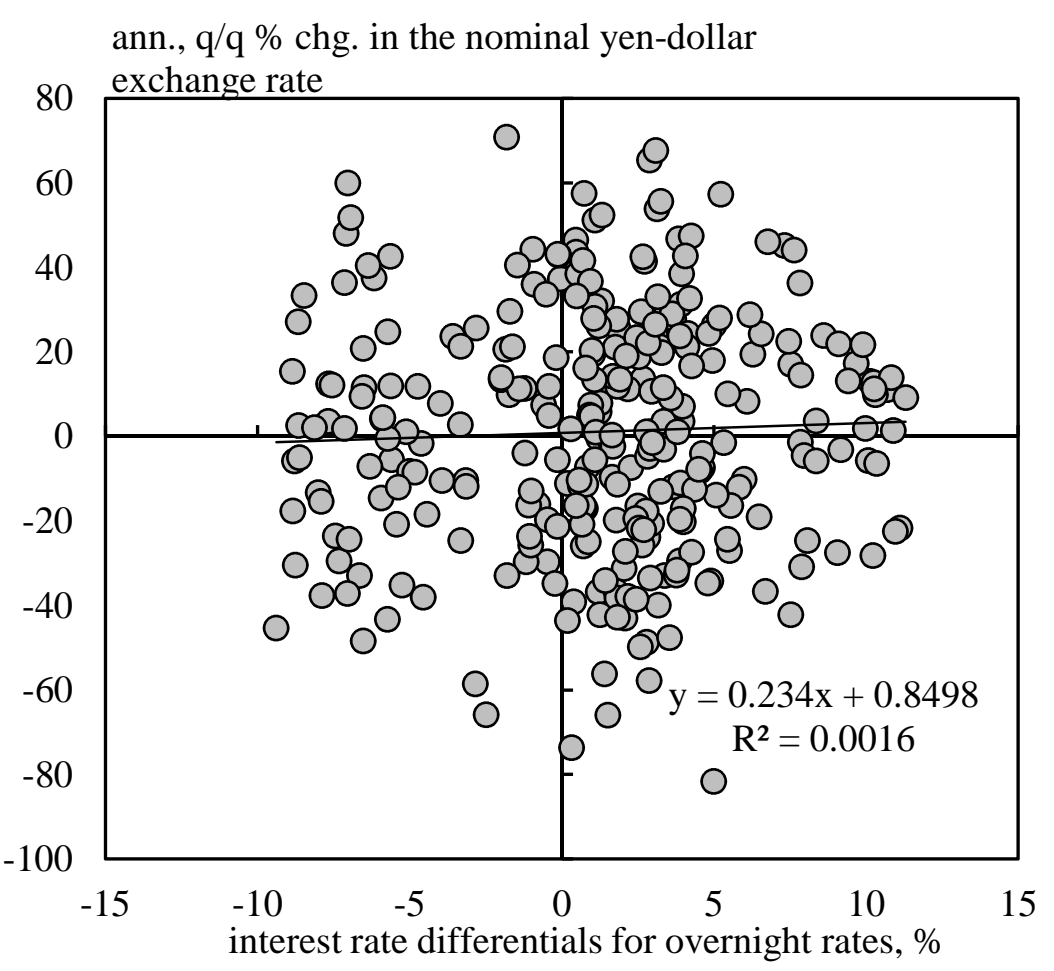

(b) 10-year Bond Yields

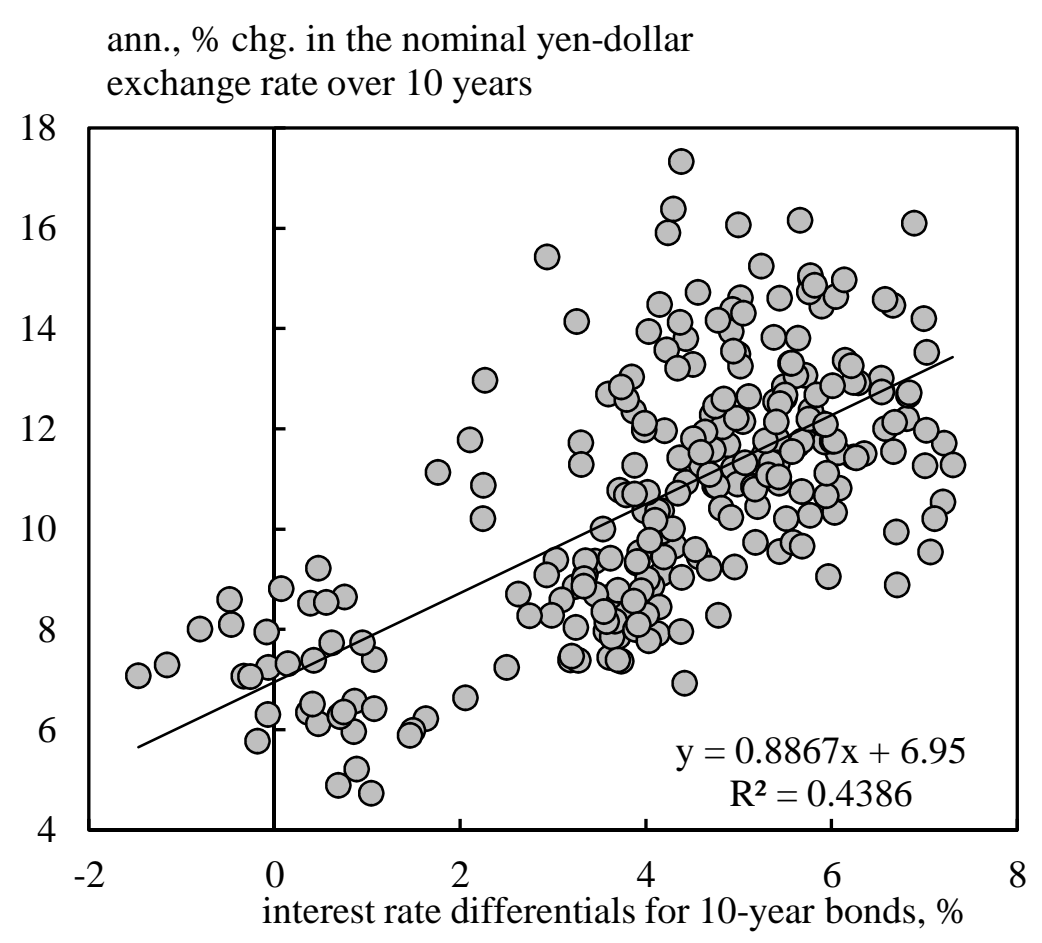

Notes: 1. The figures show interest rate differentials between $n$-year government bond yields in the U.S. and Japan at time $t$, and the yen-dollar exchange rate returns from $t$ to $t+n$ based on the samples for 300 quarters generated from our estimated model.

2. A positive exchange rate return indicates an appreciation of the yen against the U.S. dollar.

3. The interest rate differentials are calculated by subtracting interest rates in Japan from those in the U.S. 
Figure 5: Impulse Response Functions to Term Premium Shocks

(a) Nominal Yen-Dollar (Dollar/Yen) Exchange Rate

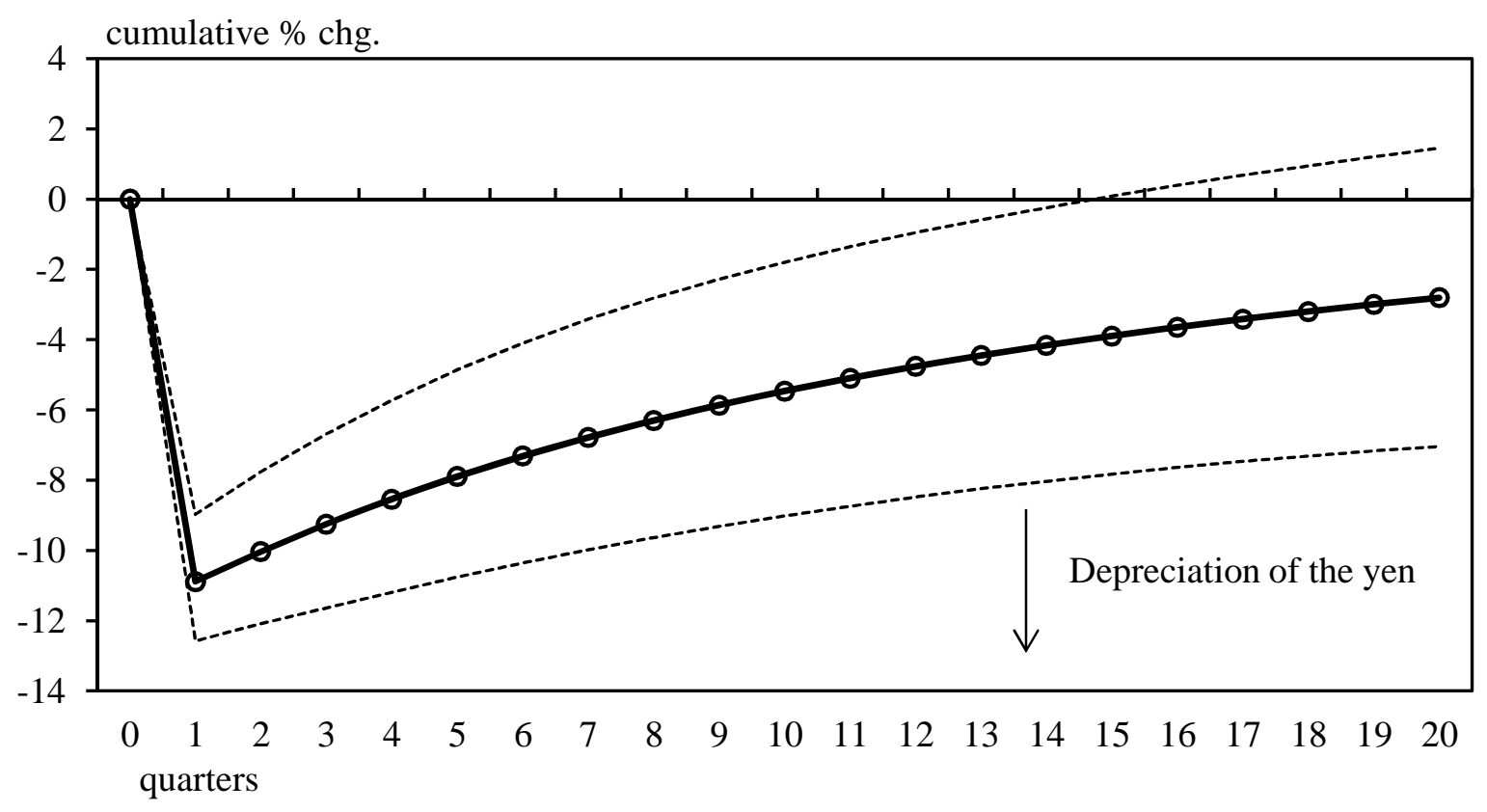

(b) CPI (less fresh foods) Inflation Rate

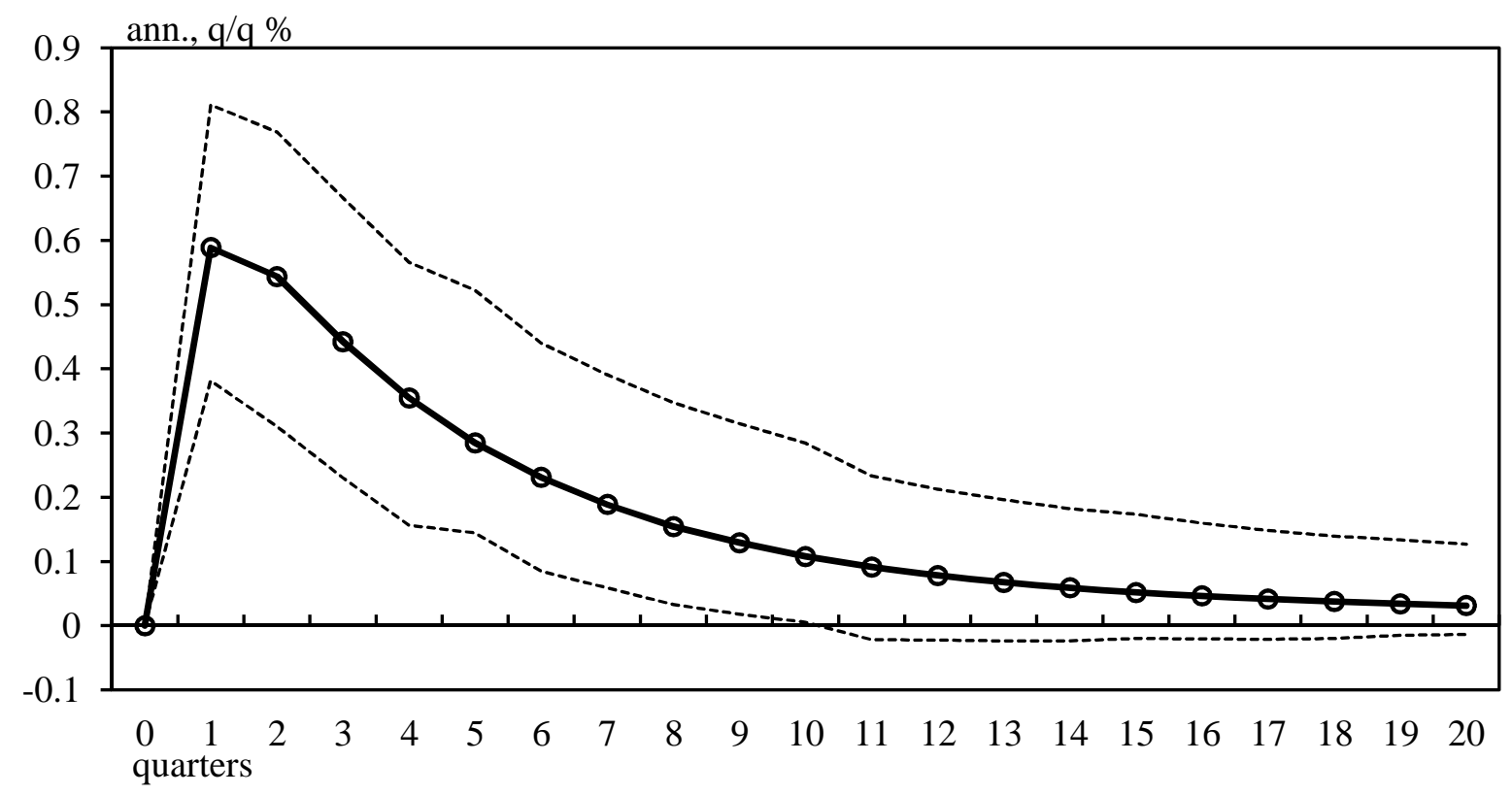

Notes: 1. The figures show the impulse response functions to a one percentage point decline in the term premium.

2. The dashed lines indicate $90 \%$ confidence intervals.

3. A positive change in the yen-dollar exchange rate indicates an appreciation of the yen against the U.S. dollar. 
Figure 6: Decomposition of Changes in the Japanese 10-year Government Bond Yields

(a) Japanese 10-year Government Bond Yields

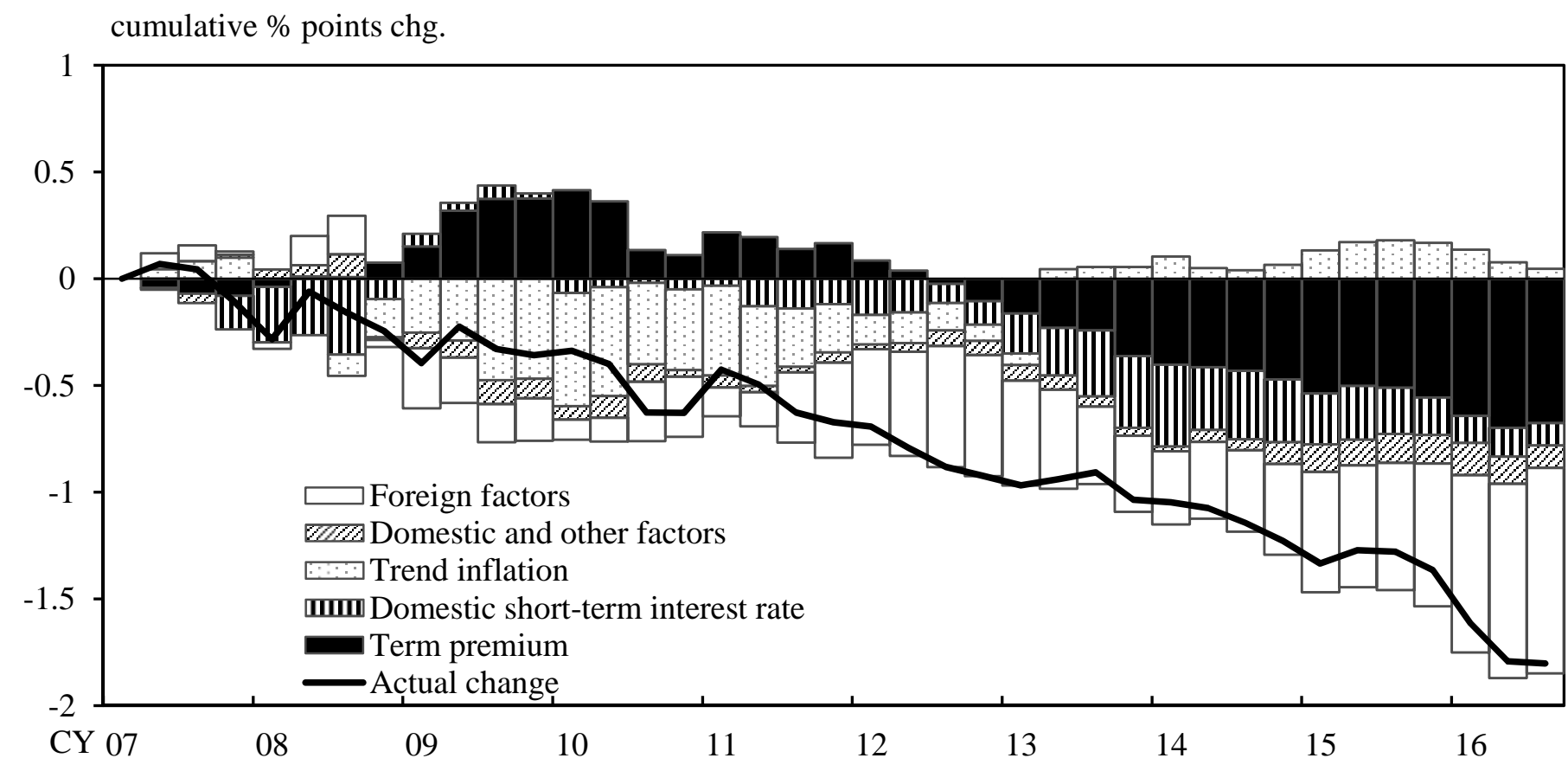

(b) Details on the Contribution of Foreign Factors to Japanese 10-year Government Bond Yields

cumulative \% points chg.

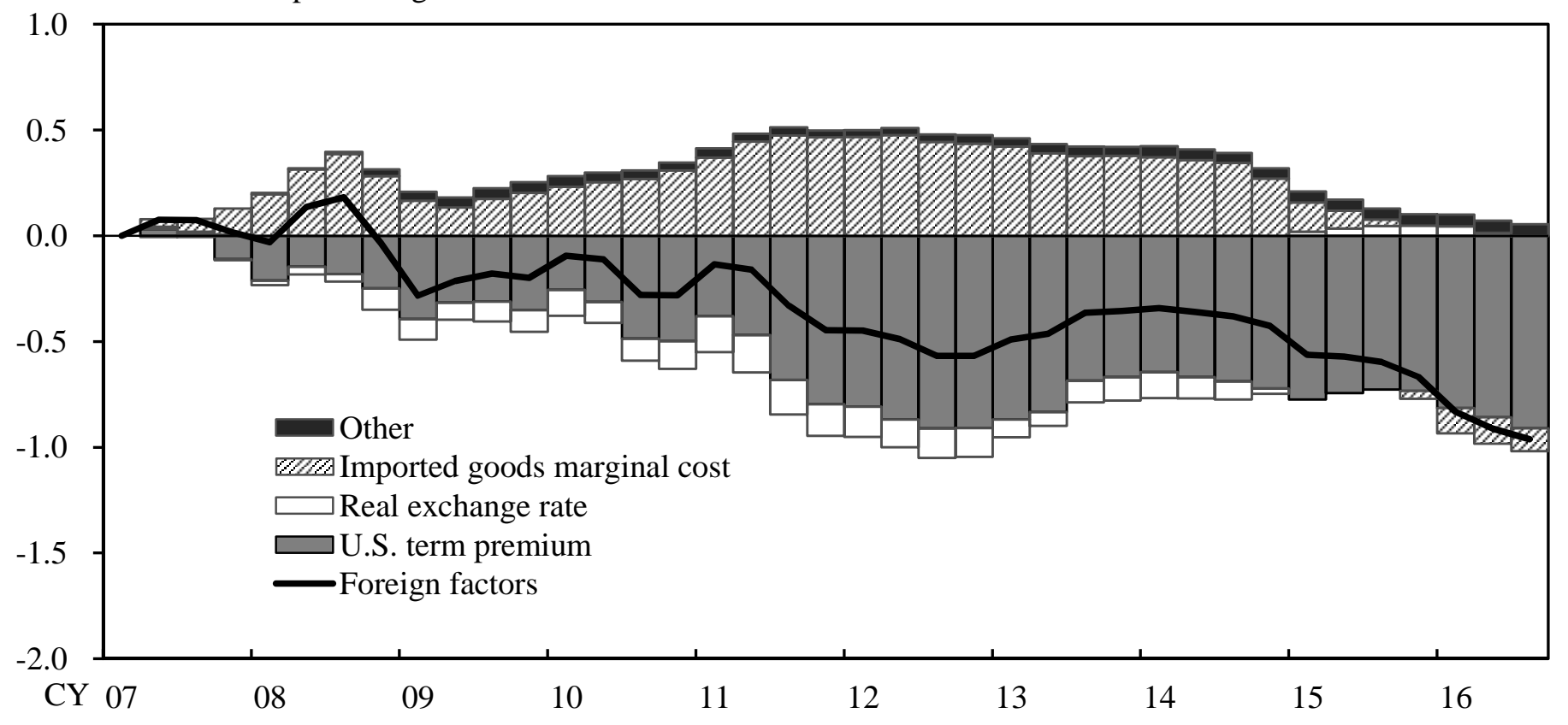

Notes: 1. Foreign factors include shocks to U.S. monetary policy, U.S. term premium, U.S. trend inflation, U.S. demand and supply, trade balance, imported good marginal cost, and real exchange rate.

Domestic short-term interest rate is defined as the sum of anticipated and unanticipated short-term interest rate shocks. Domestic and other factors include domestic productivity shocks, price markup shocks and initial values.

2. Other in Figure 6(b) includes shocks to U.S. monetary policy, U.S. trend inflation,

U.S. demand and supply, and trade balance.

3. Cumulative changes in the 10-year government bond yield are calculated from the first quarter of 2007. 
Figure 7: Decomposition of Changes in the Nominal Yen-Dollar Exchange Rate

(a) Nominal Yen-Dollar Exchange Rate

cumulative \% chg.

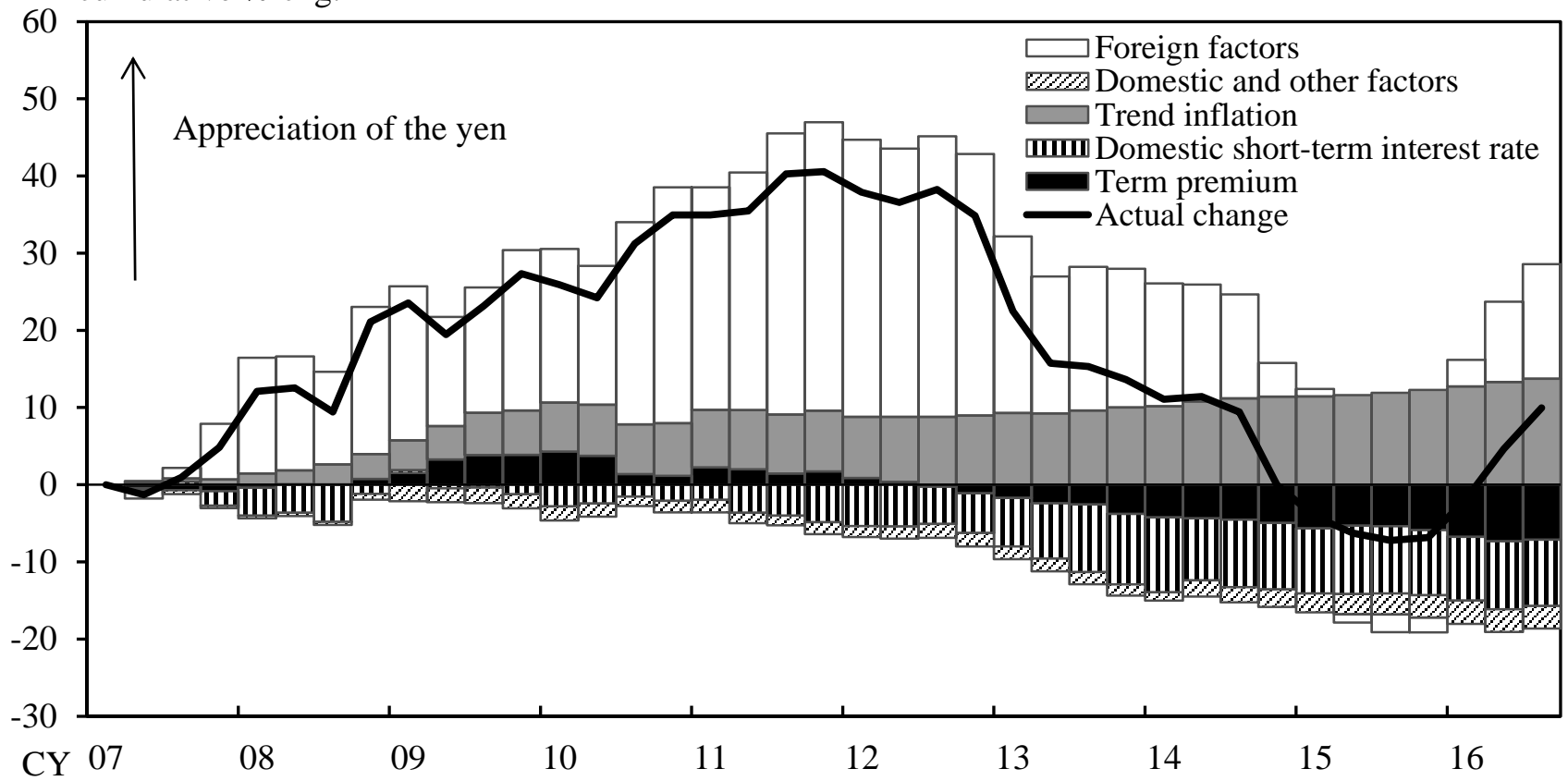

(b) Details on the Contribution of Foreign Factors to Nominal Yen-Dollar Exchange Rate

cumulative \% chg.

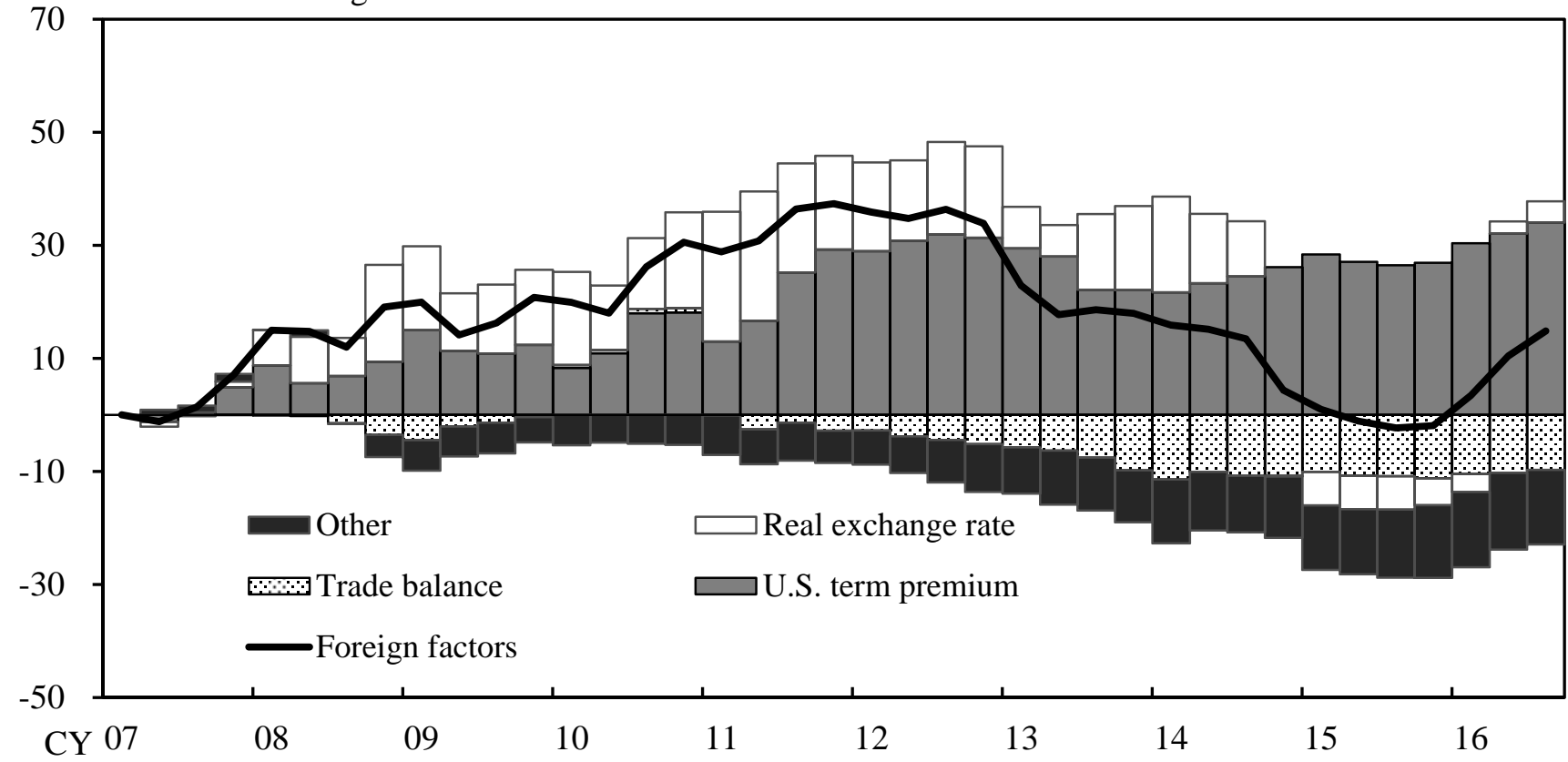

Notes: 1. See the notes on Figure 6 for the definition of the factors in Figure 7(a).

2. Other in Figure 7(b) includes shocks to U.S. monetary policy, U.S. trend inflation, U.S. demand and supply, and imported good marginal cost.

3. Cumulative changes in the nominal exchange rate are calculated from the first quarter of 2007. 
Figure 8: Decomposition of the CPI Inflation Rate

(a) CPI (less fresh foods) Inflation Rate

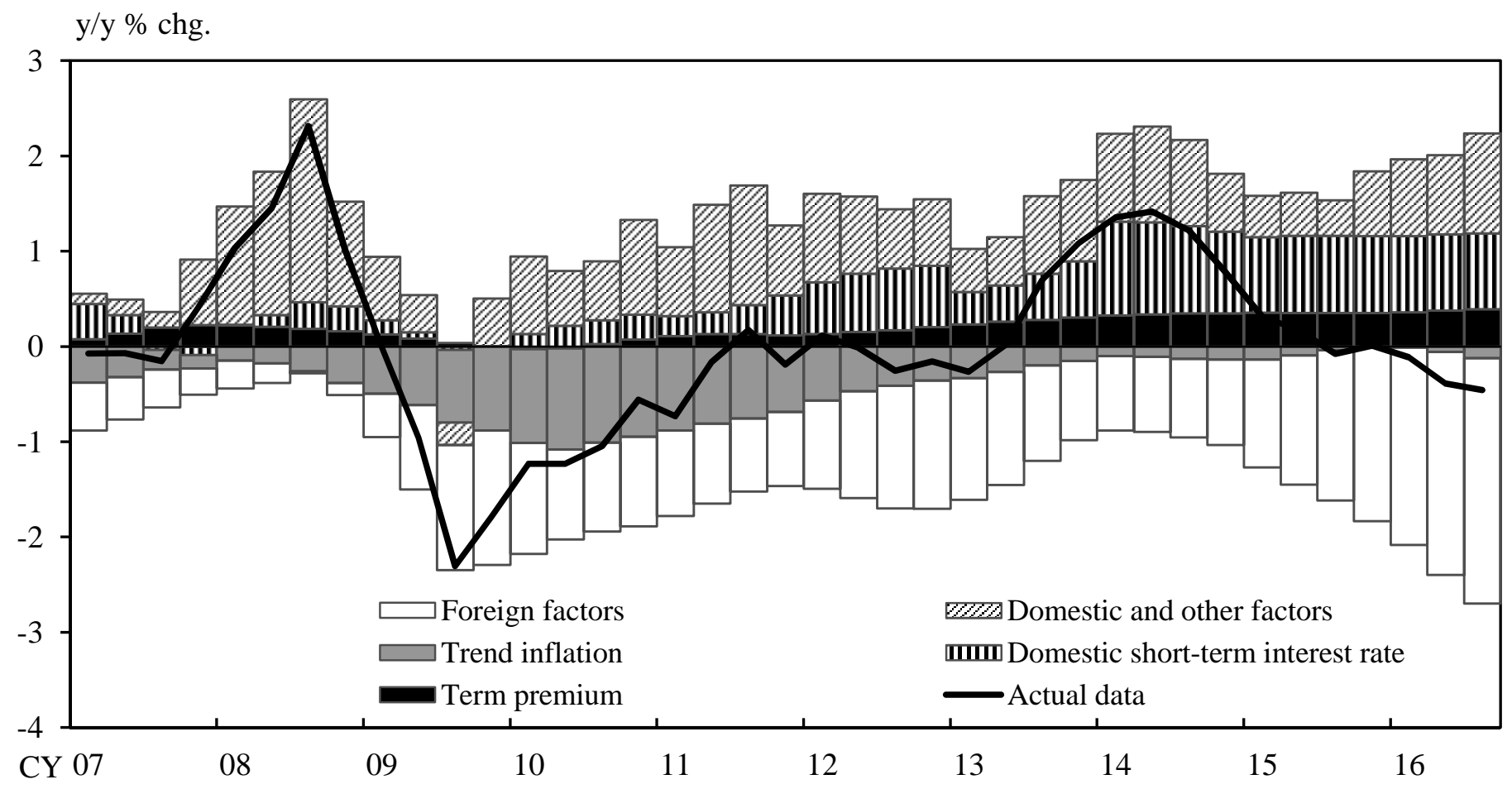

(b) Details on the Contribution of Foreign Factors to the Inflation Rate

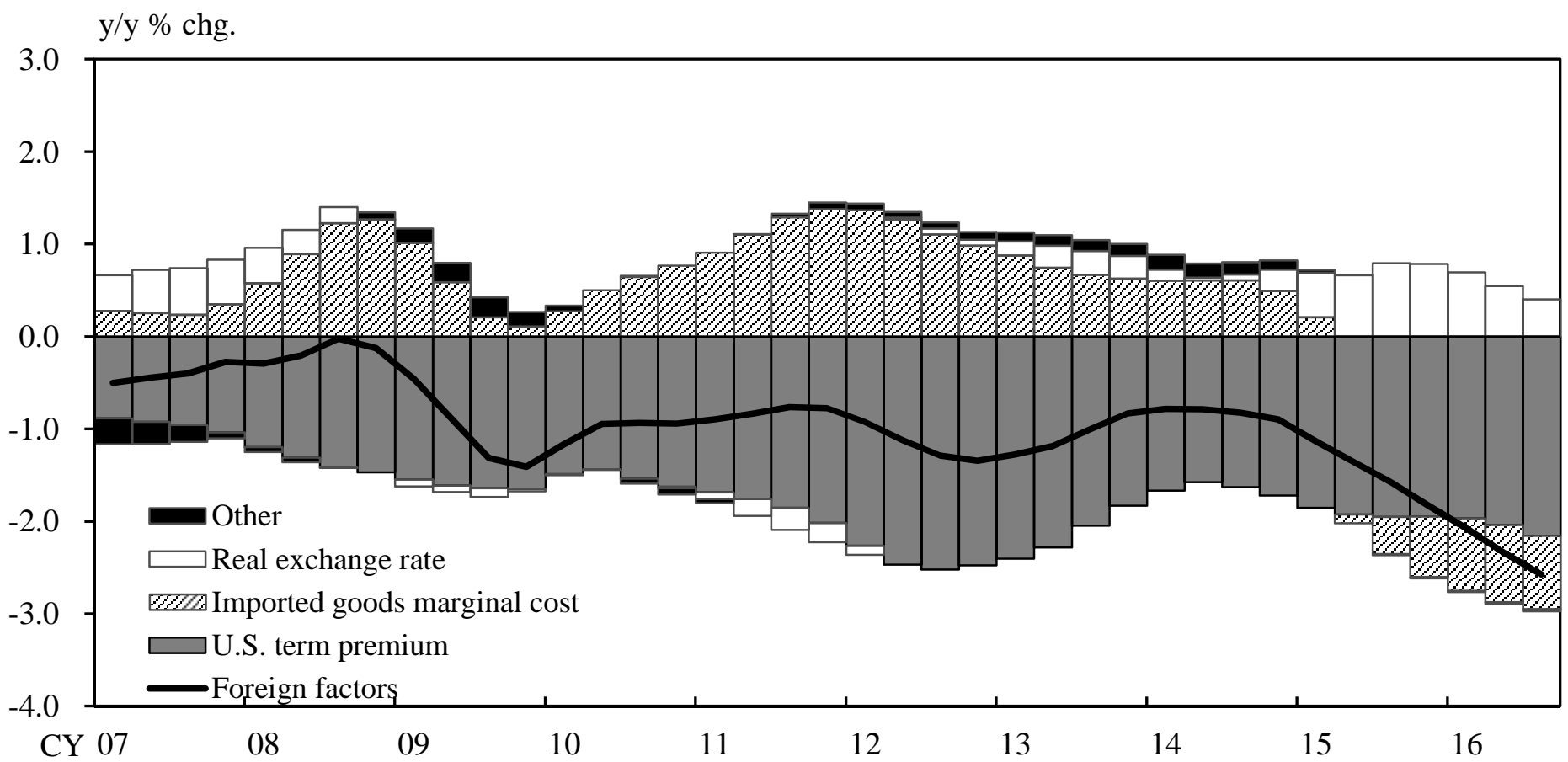

Notes: 1. See the notes on Figure 6 for the definition of the factors in Figure 8(a).

2. Other in Figure 8(b) includes shocks to U.S. monetary policy, U.S. trend inflation,

U.S. demand and supply, and trade balance.

3. Figures for the CPI are adjusted to exclude the estimated effects of changes in the consumption tax rate.

Source: Ministry of Internal Affairs and Communications. 